\title{
Bibliography
}

\author{
Primary sources
}

Archival sources

Archiv des Allgemeinen Deutschen Lehrerinnenvereins (ADLV), Berlin

Collections 7, 10, 11, 12, 15, 16

Archiv des Bundes Deutscher Frauenvereine (BdF), Berlin

Collections 1, 3, 7, 8, 10, 11, 12, 14, 15

Archiv des Deutsch-Evangelischen Frauenbundes, Archiv der deutschen Frauenbewegung, Kassel (ADEF)

Collections (Mappen) A, B, E, F, G, K, N, O, P, Q

Archiv des Katholischen Deutschen Frauenbundes, Cologne (AKDFB)

Collections (Mappen) 1-15, 1-16, 1-17, 1-22, 1-43, 1-44, 1-47, 1-108

Bayerisches Hauptstaatsarchiv, Munich

MInn Bavarian Interior Ministry

Bundesarchiv Berlin (BAB)

60 Vo 1 Deutsche Volkspartei

60 Vo 2 Deutschnationale Volkspartei

61 Re Reichslandbund

62 DAF Deutsche Arbeitsfront

R1501 Reichministerium des Innern

R1507 Reichskommissar für die Überwachnung der öffentlichen Ordnung

R3201 Reichsministerium für wirtschaftliche Demobilmuchung

R3901 Reichsarbeitsministerium 
R703 Reichstag

R8005 Deutschnationale Volkspartei

R8034II Reichslandbund

R8083 Reichsgemeinschaft Deutscher Hausfrauen

R901 Auswärtiges Amt

Bundesarchiv Koblenz (BAK)

Kleine Erwerbungen (Kl.Erw.)

Nachlass Gertrud Bäumer

Nachlass Hermann Dietrich

Nachlass Camilla Jellinek

Nachlass Katharina von Kardorff

Nachlass Marie-Elisabeth Lüders

Nachlass Adele Schreiber

R2 Finanzministerium

R36 Deutscher Gemeindetag

R43I Reichskanzlei

R45II Deutsche Volkspartei

R45III Deutsche Demokratische Partei

R45IV Kommunistiche Partei Deutschlands

R134 Reichskommissar für die Überwachnung der öffentlichen Ordnung und Nachrichtensammelstelle im Reichsministerium des Innern

Zeitgeschichtliche Sammlung (Z.Sg.)

Evangelisches Zentralarchiv Berlin

7 Evangelischer Oberkirchenrat

51 Ökumenisches Archiv

Generallandesarchiv, Karlsrube (GLA)

231 Landtag

233 Staatsministerium

235 Kultusministerium

443 Badischer Frauenverin vom Roten Kreuz

Landesarchiv Berlin (LAB)

BRep 235 Helene-Lange-Archiv (HLA)

FRep 240 Zeitgeschichtliche Sammlung

FRep 260 Plakatsammlung

Staatsarchiv Freiburg im Breisgan

317 Landeskommissär Konstanz

1257 Die politische Lage 
Staatsarchiv Hamburg (StAH)

Senat

131-10 ${ }^{1}$ Personalabteiling

Stadtarchiv Konstanz

SII Stadt Konstanz

\section{Stadtarchiv Mannheim}

S2 Ortsgeschichte

\section{Zentrales Staatsarchiv Potsdam (ZStA)}

Auswärtiges Amt

Deutschnationale Volkspartei (60 Vo 2)

Reichsarbeitsministerium

Reichskommissar für die Überwachung der öffentlichen Ordnung (St. 12)

Reichsministerium des Innern

Reichstag

\section{Published sources}

Badisches Statistisches Landesamt, Über die deutschen Nationalversammlungswablen in Baden, die badischen Gemeinde-, Bezirksrats- und Kreisabgeordnetenwahl und das Franenwablrecht (Karlsruhe: C. F. Müller, 1921)

Badisches Statistisches Landesamt, Statistisches Jahrbuch für das Land Baden 1925 (Karlsruhe: Macklot, 1925)

Badisches Statistisches Landesamt, Jahresbericht des Gewerbeaufsichts für das Jahr 1930 (Karlsruhe: Macklot'sche Druckerei, 1931)

Badisches Statistisches Landesamt, Berichte des Gewerbeaufsichtamtes für die Jahre 1933 und 1934 (Karlsruhe: Macklot, 1935)

Das gesamte deutsche und preussische Gesetzgebungsmaterial (Berlin: Verlag des Gesetzsammlungsamts, 1927)

Handbuch der verfassungsgebenden deutschen Nationalversammlung (Berlin: Carl Heymanns Verlag, 1919)

Reichsgesetzblatt

Reichstags-Handbuch. I.-VIII. Wahlperiode (Berlin: Karl Heymanns Verlag, 1919; J. Sitten Feld, 1920; Verlag der Reichsdruckerei, 1924-33) Statistisches Reichsamt, Statistik des Deutschen Reiches (Berlin)

Statistisches Reichsamt, Statistisches Jahrbuch für das Deutsche Reich (Berlin)

Stenographische Berichte über die Verhandlungen des Reichstages (Berlin) 
Newspapers, magazines and periodicals

Archiv für Bevölkerungspolitik

Die Bayerische Fran

Die christliche Frau

Evangelische Frauenzeitung

Die Frau

Die Franenfrage

Die Frau im Staat

Die Genossin

Die Gleichheit

Freiburger Zeitung

General-Anzeiger (Mannheim)

Gewerkschaftliche Frauenzeitung

Heidelberger Tagblatt

Jahrbuch für Franenarbeit

Jus suffragii

Karlsruber Zeitung

Nachrichtenblatt des Bundes deutscher Frauenvereine

Sozialistische Monatshefte

Unter dem Reichsadler

Zeitschrift des bayerischen statistischen Landesamtes

\section{Secondary sources}

\section{Contemporary published sources}

Adler, H., 'Die Gesunderhaltung der Industriearbeiterin in Beruf', Die Frau, 33:4 (January 1926), 203-12

Allgemeiner Deutscher Gewerkschaftsbund, Jabrbuch des Allgemeinen Deutschen Gewerkschaftsbundes 1927 (Berlin: Verlagsanstalt des Allgemeinen Deutschen Gewerkschaftsbundes, 1928)

Allgemeiner Deutscher Gewerkschaftsbund, Jahrbuch des Allgemeinen Deutschen Gewerkschaftsbundes 1928 (Berlin: Verlagsanstalt des Allgemeinen Deutschen Gewerkschaftsbundes, 1929)

Allgemeiner Deutscher Gewerkschaftsbund, Jahrbuch des Allgemeinen Deutschen Gewerkschaftsbundes 1930 (Berlin: Verlagsanstalt des Allgemeinen Deutschen Gewerkschaftsbundes, 1931)

Allgemeiner Deutscher Lehrerinnenverein, Leitende Stellen im Mädchenschulwesen (Hamburg: Blöß, 1926)

Allgemeiner Deutscher Lehrerinnenverein, Verhandlungen der XX. Generalversammlung des ADLV in Wien 19.-22. Mai 1929 (Berlin, 1929)

Altmann-Gottheiner, E. (ed.), Kriegsjahrbuch des Bundes Deutscher Frauenvereine 1915 (Leipzig and Berlin: Teubner, 1915) 
Altmann-Gottheimer, E. (ed.), Jahrbuch des Bundes Deutscher Frauenvereine 1920 (Berlin: Teubner, 1920)

Arbeitgeberverband der Deutschen Textilindustrie, Die Franenerwerbsarbeit in der Textilindustrie mit besonderer Berücksichtigung schwangerer Frauen (Berlin: Elsner, 1926)

Bäumer, G., 'Heimatchronik', Die Frau, 21:12 (September 1914), 748-53

Bäumer, G., Die Frau im neuen Lebensraum (Berlin: Herbig, 1931)

Bäumer, G., Die Frau im deutschen Staat (Berlin: Junker und Dünnhaupt, 1932)

Bäumer, G., 'Krisis des Frauenstudiums', Die Frau, 39:6 (March 1932), 322-7, and 39:10 (July 1932), 611-19

Bäumer, G., Lebensweg durch eine Zeitwende (Tübingen: Rainer Wunderlich Verlag, 1933)

Bäumer, G., Des Lebens wie der Liebe Band: Briefe, ed. E. Beckmann (Tübingen: Wunderlich, 1956)

Barck, L., Ziele und Aufgaben der weiblichen Polizei in Deutschland (Berlin: Deutscher Polizei-Verlag, 1928)

Beyer, H., Die Frau in der politischen Entscheidung (Stuttgart: Enke, 1933)

Blos, A. (ed.), Die Frauenfrage im Lichte des Sozialismus (Dresden: Kadan, 1930)

Blücher, Evelyn, Princess, An English Wife in Berlin (New York: E. P. Dutton \& Company, 1920)

Burgdörfer, F., Der Geburtenrückgang und seine Bekämpfung: Die Lebensfrage des deutschen Volkes (Berlin: Schoetz, 1929)

Burgdörfer, F., Zurück zum Agrar-Staat? Stadt und Land in volksbiologischer Betrachtung (Berlin: Kurt Vowinckel, 1933)

Cooper, C. E., Behind the Lines: One Woman's War 1914-18, ed. D. Denholm (Sydney: Collins, 1982)

Deutsch, R., Die politische Tat der Frau (Gotha: Perthes, 1920)

Deutsch, R., Zwei Jahre parlamentarischer Franenarbeit (Gotha: Perthes, 1923)

Deutsch, R., Parlamentarische Frauenarbeit II: Aus den Reichstagen von 1924-1928 (Berlin: Herbig, 1928)

Deutscher Metallarbeiterverband, Die Franenarbeit in der Metallindustrie (Stuttgart: Deutscher Metallarbeiterverband, 1930)

Deutscher Textilarbeiterverband, Umfang der Frauenarbeit in der deutschen Textilindustrie (Berlin: Verlag Deutscher Textilarbeiterverband, 1923)

Deutscher Textilarbeiterverband, Erwerbsarbeit, Schwangerschaft, Frauenleid (Berlin: Verlag Deutscher Textilarbeiterverband, 1925)

Deutscher Textilarbeiterverband (ed.), Mein Arbeitstag-mein Wochenende (Berlin: Textilpraxis, 1928)

Diehl, G., Was wir wollen: Frage und Antwort über den Neulandbund (Eisenach: Neulandverlag, 1918) 
Frauenliga für Frieden und Freiheit (Deutsches Zweig), Völkerversöhnende Frauenarbeit (Munich: Heller, 1920)

Frick, W., Die Nationalsozialisten im Reichstag 1924-1931 (Munich: Eher, 1932)

Fuss, H., 'Unemployment and Employment among Women', International Labour Review, 31 (1935), 463-97

Gaebel, K., 'Die Berufslage der Akademikerinnen', Die Frau, 34:4 (January 1927), 218-24, and 34:5 (February 1927), 238-82

Gaebel, K., Die deutsche Wirtschaft und das Berufsschicksal der Frau (Berlin: Bund Deutscher Frauenvereine, 1932)

Gerard, J. W., My Four Years in Germany (London: Hodder and Stoughton, 1917)

Gewerkschaftsbund der Angestellten, Die wirtschaftliche und soziale Lage der Angestellten (Berlin: Sieben-Stäbe-Verlag, 1931)

Glass, F., and D. Kische, Die wirtschaftlichen und sozialen Verhältnisse der berufstätigen Frauen (Berlin: Heymann, 1930)

Goetz, K., 'Die Ehescheidungen im Deutschen Reich', Die Frau, 35:2 (November 1927), 94-7

Goldschmidt, H., 'The Application in Germany of the Washington Convention concerning the Employment of Women before and after Childbirth', International Labour Review, 16 (1927), 637-47

Grünfeld, J., 'Das Lohnproblem der Arbeiterin', Die Arbeit, 6 (1929), 445-53

Grünfeld, J., 'Frauenarbeit im Lichte der Rationalisierung', Die Arbeit, 8 (1931), 911-24

Grünfeld, J., 'Rationalisation and the Employment and Wages of Women in Germany', International Labour Review, 29 (1934), 605-32

Hanna, G., 'Women in the German Trade Union Movement', International Labour Review, 8 (1923), 21-37

Hartwig, Dr, 'Wie die Frauen im Deutschen Reich von ihrem politischen Wahlrecht Gebrauch machen', Allgemeines statistisches Archiv, 17 (1928), 497-512

Hartwig, Dr, 'Das Frauenwahlrecht in der Statistik', Allgemeines statistisches Archiv, 21 (1931), 167-82

Hellersberg, M., Die soziale Not der weiblichen Angestellten (Berlin: Sieben-Stäbe-Verlag, 1928)

Hermann, E., 'This is the New Woman', in A. Kaes, M. Jay and E. Dimendberg (eds), The Weimar Republic Sourcebook (Berkeley: University of California Press, 1994), pp. 206-7

Hoffmann, E., Die Gemeindewablen in Mannheim 1911-1930 (Mannheim: Gengenbach \& Hahn, 1932)

Jabrbuch der deutschen Sozialdemokratie (Berlin: J. H. W. Dietz, 1930)

Jellinek, C., Frauen unter deutschem Recht (Mannheim: Bensheimer, 1928) 
Jende-Radomski, H., Frauenberufe (Dessau: Dünnhaupt, 1926)

Karbe, A., Die Frauenlohnfrage und ibre Entwicklung in der Kriegs- und Nachkriegszeit (Rostock: C. Hinstorffs, 1928)

Kempf, R., Die deutsche Frau nach der Volks-, Berufs- und Betriebszählung von 1925 (Mannheim: Bennsheimer Verlag, 1931)

Kempf, R., 'Die Stellung der Frau in der deutschen Landwirtschaft', in A. Schmidt-Beil (ed.), Die Kultur der Frau (Berlin: Verlag für Kultur und Wissenschaft, 1931), pp.98-11

Kern, K., Frauen, entscheidet Euch! (Berlin: J. H. W. Dietz, 1931)

König, J. K., Seid fruchtbar und mehret Euch! (Berlin: Verlagsanstalt der Proletarischen Freidenker, 1931)

Kropff, H., 'Women as Shoppers', in A. Kaes, M. Jay and E. Dimendberg (eds), The Weimar Republic Sourcebook (Berkeley: University of California Press, 1994), pp.660-2

Kuhr, P., There We'll Meet Again: The First World War Diary of a Young German Girl, trans. W. Wright (Gloucester: Walter Wright, 1998)

Kuntze, L., 'The Extension of German Women's Work in War Time', Jus suffragii, 11:4 (1 February 1917), 66-7

Lange, H., Die Frauenbewegung in ibren gegenwärtigen Problemen (Leipzig: Quelle \& Meyer, 3rd edn, 1924)

Lange, H., Was ich hier geliebt: Briefe von Helene Lange, ed. E. Beckmann (Tübingen: Wunderlich, 1957)

Lorenz, C., 'Die gewerbliche Frauenarbeit während des Krieges', in J. T. Shotwell (ed.), Der Krieg und die Arbeitsverhältnisse (Stuttgart: Deutsche Verlagsanstalt, 1928), pp.311-91

Lüders, E., 'The Effects of German Labour Legislation on Employment Possibilities for Women', International Labour Review, 20 (1929), 385-96

Lüders, M.-E., 'Die Entwicklung der gewerblichen Frauenarbeit im Kriege', Schmollers Jahrbuch für Gesetzgebung, Verwaltung und Volkswirtschaft im Deutschen Reiche, 44 (1920), 241-75 and 569-93

Magnus-Hausen, F., Zehn Jahre deutsche Staatsbürgerin (Berlin: Herbig, 1930)

Meerwarth, R., A., Günther and W. Zimmermann, Die Einwirkung des Krieges auf Bevölkerungsbewegung, Einkommen und Lebenshaltung in Deutschland (Stuttgart: Deutsche Verlagsanstalt, 1932)

Meusel, M., Lebensverhältnisse lediger Mütter auf dem Lande (Berlin: Müller, 1933)

Munk, M., Vorschläge zur Umgestaltung des Rechts der Ehescheidung und der elterlichen Gewalt nebst Gesetzentwurf (Berlin: Herbig, 1923)

Munk, M., Recht und Rechtsverfolgung im Familienrecht (Berlin: Liebmann, 1929)

Nationaler Frauendienst, Der Nationale Frauendienst in Berlin, 1914-17 (Berlin: Vaterländische Verlags- und Kunstanstalt, 1917) 
Opet, O., and W. von Blume (eds), Das Familienrecht des Bürgerlichen Gesetzbuches (Berlin: Heymann, 1906)

Ostwald, H., Sittengeschichte der Inflation (Berlin: Neufeld \& Henius, 1931)

Pius XI (Papa), Rundschreiben über die gesellschaftliche Ordnung (Freiburg im Breisgau: Herder, 1931)

Protokoll über die Verhandlungen des Parteitages der Sozialdemokratischen Partei Deutschlands abgehalten in Weimar vom 10. bis 15. Juni 1919 (Berlin: Buchhaltung Vorwärts Paul Singer, 1919)

Rabe, S., Die Frau im nationalsozialistischen Staate (Munich: Münchener Druck- und Verlagshaus, 1932)

Reichsorganisationsleiter der NSDAP (ed.), NSDAP Partei-Statistik (Munich: Zentralverlag der NSDAP, 1935)

Rühle-Gerstel, A., Das Frauenproblem der Gegenwart: Eine psychologische Bilanz (Leipzig: Verlag von S. Hirzel, 1932)

Salomon, A., 'Women's Hopes for the New Order', Jus suffragii, 13:5 (February 1919), 62

Schmidt-Beil, A. (ed.), Die Kultur der Frau (Berlin: Verlag für Kultur und Wissenschaft, 1931)

Silberkühl-Schulte, M., 'Die Landfrauenfrage', Die Frau, 40:6 (March 1933), 361-5

Sozialdemokratische Partei Deutschlands, Reichstag und Frauenrechte (Weimar: Verlag SPD Bezirksverband Grossthüringen, 1924)

Sozialdemokratischer Parteitag 1924 (Berlin: J. H. W. Dietz, 1924)

Sozialdemokratischer Parteitag 1925 in Heidelberg (Berlin: J. H. W. Dietz, 1925)

Sozialdemokratischer Parteitag 1927 in Kiel (Berlin: J. H. W. Dietz, 1927)

Strasser, I., Frauenarbeit und Rationalisierung (Berlin: Verlag der Roten Gewerkschafts-Internationale, 1927)

Stritt, M., 'German Women have Got the Vote', Jus suffragii, 13:4 (January 1919), 44-6

Stritt, M., 'Germany', Jus suffragii, 13:6 (March 1919), 76

Süersen, E., Die Frau im Deutschen Reichs- und Landesstaatsdienst (Mannheim: Bensheimer, 1920)

Suhr, S., Die weiblichen Angestellten (Berlin: Zentralverband der Angestellten, 1930)

Sveistrup, H., and A. von Zahn-Harnack (eds), Die Franenfrage in Deutschland: Strömungen und Gegenströmungen, 1790-1930 (Magdeburg: Burg, 1934)

Thibert, M., 'The Economic Depression and the Employment of Women', International Labour Review, 27 (April 1933), 443-70, and 27 (May 1933), 620-30

Verein Katholischer Deutscher Lehrerinnen, Statistische Erhebungen über 
die wirtschaftlichen Verhältnisse der Lehrerinnen (Paderborn: Ferdinand Schöningh, 1928)

Verhandlungen derverfassungsgebenden Deutschen Nationalversammlung, vol. 329 (Berlin: Druck und Verlag der Nordeutschen Buchdruckerei und Verlags-Anstalt, 1920)

Verhandlungen der verfassungsgebenden Deutschen Nationalversammlung, vol. 338 (Berlin: Julius Sittenfeld, 1920)

Weiss, M. (ed.), Politisches Handwörterbuch (Führer ABC) (Berlin: Deutschnationale Schriftenvertriebsstelle, 1928)

Wex, E., Staatsbürgerliche Arbeit deutscher Frauen 1865 bis 1928 (Berlin: Herbig, 1929)

Wolff, E. (ed.), Jabrbuch des Bundes Deutscher Franenvereine 1927-28 (Mannheim: J. Bensheimer, 1929)

Wolff, E. (ed.), Jahrbuch des Bundes Deutscher Frauenvereine 1932 (Berlin and Leipzig: Bensheimer, 1932)

Wurm, M., Die Franenerwerbsarbeit: Rede auf der Leipziger Frauenkonferenz am 29. November 1919 (Berlin: 'Freiheit', 1920)

Zentrale der KPD, Referentenmaterial: Mutter und Kind in Deutschland und Russland (Berlin: Zentrale der KPD, 1926)

\section{Books and articles}

Abrams, L., 'From Control to Commercialisation: The Triumph of Mass Entertainment in Germany, 1900-25?', German History, 8:3 (1990), 278-93

Albisetti, J., Schooling German Girls and Women (Princeton: Princeton University Press, 1988)

Allen, A. T., Feminism and Motherhood in Germany 1800-1914 (New Brunswick: Rutgers University Press, 1991)

Allen, A. T., 'Feminism, Venereal Diseases, and the State in Germany', Journal of the History of Sexuality, 4:1 (1993), 27-50

Allen, A. T., 'Feminism and Eugenics in Germany and Britain, 1900-1940: A Comparative Perspective', German Studies Review, 23:3 (2000), 477-505

Allen, A. T., Feminism and Motherhood in Western Europe, 1890-1970 (Basingstoke: Palgrave Macmillan, 2005)

Allen, K., 'Sharing Scarcity: Bread Rationing and the First World War in Berlin, 1914-1923', Journal of Social History, 32:2 (1998), 371-93

Allen, K., 'Food and the German Home Front: Evidence from Berlin', in G. Braybon (ed.), Evidence, History, and the Great War: Historians and the Impact of 1914-18 (Oxford: Berghahn, 2003), pp. 172-97

Altenhoner, F., 'Das "Heimatheer deutscher Frauen": Propaganda durch bürgerliche Frauen in Berlin 1918 zwischen Aufklärung und Denunziation', Ariadne, 47 (May 2005), 38-43 
Ankum, K. von, 'Gendered Urban Spaces in Irmgard Keun's Das kunstseidene Mädchen', in K. von Ankum (ed.), Women in the Metropolis: Gender and Modernity in Weimar Culture (Berkeley: University of California Press, 1997), pp.162-84

Ankum, K. von (ed.), Women in the Metropolis: Gender and Modernity in Weimar Culture (Berkeley: University of California Press, 1997)

Arendt, H.-J., 'Das Schutzprogramm der KPD für die arbeitende Frau vom 15. Oktober 1931', Beiträge zur Geschichte der Arbeiterbewegung, 11:2 (1969), 291-311

Arendt, H.-J., 'Weibliche Mitglieder der KPD in der Weimarer Republik zahlenmässige Stärke und soziale Stellung', Beiträge zur Geschichte der Arbeiterbewegung, 19 (1977), 652-60

Arendt,H.-J., 'Die “Gleichschaltung” der bürgerlichen Frauenorganisationen in Deutschland 1933/34', Zeitschrift für Geschichtswissenschaft, 27 (1979), 615-27

Arendt, H.-J., 'Weibliche Opfer militäristischen Terrors in Deutschland (1918-1920)', Beiträge zur Geschichte der Arbeiterbewegung, 26:2 (1984), 228-37

Arendt, H.-J., and W. Freigang, 'Der Rote Frauen- und Mädchenbund - die revolutionäre deutsche Frauenorganisation in der Weimarer Republik', Beiträge zur Geschichte der Arbeiterbewegung, 21 (1979), 249-58

Arendt, H.-J., S. Hering and L. Wagner (eds), Nationalsozialistische Frauenpolitik vor 1933 (Frankfurt am Main: Dipa Verlag, 1995)

Arendt, H.-J., J. Kirchner, J. Müller, E. Schotte and F. Staude (eds), Dokumente der revolutionären deutschen Frauenbewegung zur Franenfrage, 1848-1974 (Leipzig: Verlag für die Frau, 1975)

Bajohr, S., Die Hälfte der Fabrik: Geschichte der Franenarbeit in Deutschland 1914 bis 1945 (Marburg: Verlag Arbeiterbewegung und Gesellschaftswissenschaft, 1979)

Bajohr, S., 'Sexualaufklärung im proletarischen Milieu, Geschlechtskrankheiten und staatliche Eheberatung 1900 bis 1933', in P. Pasteur, N. Niederacher and M. Mesner (eds), Sexualität, Unterschichtenmilieus und ArbeiterInnenbewegung (Leipzig: Akademische Verlagsanstalt, 2003), pp. 59-69

Bajohr, S., and K. Rödiger-Bajohr, 'Die Diskriminierung der Juristin in Deutschland bis 1945', Kritische Justiz, 13:1 (1980), 39-51

Baranowski, S., Strength through Joy: Consumerism and Mass Tourism in the Third Reich (Cambridge: Cambridge University Press, 2004)

Barndt, K., 'Aesthetics of Crisis: Motherhood, Abortion, and Melodrama in Irmgard Keun and Friedrich Wolf', Women in German Yearbook: Feminist Studies in German Literature and Culture, 24 (2008), 71-95

Barndt, K., 'Mothers, Citizens, and Consumers: Female Readers in Weimar Germany', in K. Canning, K. Barndt and K. McGuire (eds), Weimar 
Publics / Weimar Subjects: Rethinking the Political Culture of Germany in the 1920s (Oxford: Berghahn, 2010), pp.95-115

Baum, M., Rückblick auf mein Leben (Heidelberg: Kerle, 1950)

Baumann, U., 'Religion, Emancipation, and Politics in the Confessional Women's Movement in Germany, 1900-1933', in B. Melman (ed.), Borderlines: Genders and Identities in War and Peace, 1870-1930 (London: Routledge, 1998), pp.285-306

Benker, G., Studentinnen in der Weimarer Republik (Pfaffenweiler: Centaurus-Verlag, 1990)

Benninghaus, C., Die anderen Jugendlichen: Arbeitermädchen in der Weimarer Republik (Frankfurt: Campus, 1994)

Benninghaus, C., 'Mothers' Toil and Daughters' Leisure: Working-Class Girls and Time in 1920s' Germany', History Workshop Journal, 50 (2000), 45-72

Berghaus, G., 'Girlkultur - Feminism, Americanism, and Popular Entertainment in Weimar Germany', Journal of Design History, 1:3-4 (1988), 193-219

Bergmann, C., What Will Become of the Children?, trans. R. Bodek (Rochester: Camden House, 2010)

Berliner Geschichtswerkstatt e.V. (ed.), August 1914: Ein Volk zieht in den Krieg (Berlin: Nishen, 1989)

Berntson, M. A., and B. Ault, 'Gender and Nazism: Women Joiners of the Pre-1933 Nazi Party', American Behavioral Scientist, 41 (1998), 1193-1218

Bessel, R., "“Eine nicht allzu grosse Beunruhigung des Arbeitsmarktes”: Frauenarbeit und Demobilmachung in Deutschland nach dem Ersten Weltkrieg', Geschichte und Gesellschaft, 9 (1983), 211-29

Bessel, R., Germany after the First World War (Oxford: Clarendon Press, 1993)

Bessel, R., 'Mobilizing German Society for War', in R. Chickering and S. Förster (eds), Great War, Total War: Combat and Mobilization on the Western Front, 1914-1918 (Cambridge: Cambridge University Press, 2000), pp.437-51

Bessel, R., 'Unemployment and Demobilisation in Germany after the First World War', in R. J. Evans and D. Geary (eds), The German Unemployed: Experiences and Consequences of Mass Unemployment from the Weimar Republic to the Third Reich (London: Croom Helm, 1987), pp. 23-43

Birkett, J., and E. Harvey (eds), Determined Women: Studies in the Construction of the Female Subject, 1900-1990 (London: Macmillan, 1991)

Blackbourn, D., and G. Eley, The Peculiarities of German History: Bourgeois Society and Politics in Nineteenth-Century Germany (Oxford: Oxford University Press, 1984) 
Blasius, D., Ehescheidung in Deutschland 1794-1945 (Göttingen: Vandenhoeck \& Ruprecht, 1987)

Blom, I., K. Hagemann and C. Hall (eds), Gendered Nations: Nationalisms and Gender Order in the Long Nineteenth Century (Oxford: Berg, 2000) Boak, H. L., “"Our last hope”: Women's Votes for Hitler - A Reappraisal', German Studies Review, 12:2 (May 1989), 289-310

Boak, H., 'The State as an Employer of Women in the Weimar Republic', in W. R. Lee and E. Rosenhaft (eds), The State and Social Change in Germany, 1880-1980 (London: Berg, 1990), pp. 61-98

Boak, H., 'Women in Weimar Politics', European History Quarterly, 20:3 (1990), 369-99

Boak, H., 'National Socialism and Working-Class Women before 1933', in C. Fischer (ed.), The Rise of National Socialism and the Working Classes in Weimar Germany (Oxford: Berghahn, 1996), pp.163-88

Boak, H., 'Mobilising Women for Hitler: The Female Nazi Voter', in A. McElligott and T. Kirk (eds), Working towards the Führer (Manchester: Manchester University Press, 2003), pp. 68-92

Boedeker, E., 25 Jahre Frauenstudium in Deutschland, vol. 1 (Hanover: C. Trute, 1939)

Bölke, C., Die Wandlung der Frauenemanzipationsbewegung von Marx bis zur Rätebewegung (Hamburg: Verlag Association, 1975)

Bonzon, T., and B. Davis, 'Feeding the Cities', in J. Winter and J.-L. Robert (eds), Capital Cities at War: Paris, London, Berlin 1914-1919 (Cambridge: Cambridge University Press, 1997), pp.305-41

Boxer, M. J., and J. H. Quataert (eds), Connecting Spheres: Women in the Western World, 1500 to the Present (Oxford: Oxford University Press, 1987)

Brand, M. B. von, Die Frau in der deutschen Landwirtschaft (Berlin: F. Vahlen, 1939)

Bremme, G., Die politische Rolle der Frau in Deutschland (Göttingen: Vandenhoeck \& Ruprecht, 1956)

Bridenthal, R., 'Beyond Kinder, Küche, Kirche: Weimar Women at Work', Central European History, 6:2 (1973), 148-66

Bridenthal, R., 'Class Struggle around the Hearth: Women and Domestic Service in the Weimar Republic', in M. Dobkowski and I. Wallimann (eds), Towards the Holocaust: The Social and Economic Collapse of the Weimar Republic (Westport: Greenwood, 1983), pp. 243-64

Bridenthal, R., and C. Koonz, 'Beyond Kinder, Küche, Kirche: Weimar Women in Politics and Work', in B. A. Carroll (ed.), Liberating Women's History (Chicago: University of Illinois Press, 1976), pp.301-29

Bridenthal, R., A. Grossmann and M. Kaplan (eds), When Biology became Destiny: Women in Weimar and Nazi Germany (New York: Monthly Review Press, 1984) 
Brockmann, S., 'Weimar Sexual Cynicism', in T. W. Kniesche and S. Brockmann (eds), Dancing on the Volcano: Essays on the Culture of the Weimar Republic (Columbia: Camden House, 1994), pp. 165-80

Brocks, C., Die bunte Welt des Krieges: Bildpostkarten aus dem Ersten Weltkrieg (Essen: Klartext, 2008)

Bry, G., Wages in Germany, 1871-1945 (Princeton: Princeton University Press, 1960)

Buerkle, D., 'Gendered Spectatorship, Jewish Women and Psychological Advertising in Weimar Germany', Women's History Review, 15:4 (2006), 625-36

Bussemer, H.-U. “"Weit hinter den Schützengräben”. Das Kriegserlebnis der bürgerlichen Frauenbewegung', in Berliner Geschichtswerkstatt e. V. (ed.), August 1914: Ein Volk zieht in den Krieg (Berlin: Nishen, 1989), pp. 136-46

Büttner, U., Weimar: Die überforderte Republik 1918-1933 (Stuttgart: Klett-Cotta, 2008)

Canning, K., Gender History in Practice: Historical Perspectives on Bodies, Class and Citizenship (Ithaca, NY: Cornell University Press, 2006)

Canning, K., 'Sexual Crisis and the Writing of Citizenship: Reflections on States of Exception in Germany, 1914-1920', in A. Lüdtke and M. Wildt (eds), Ausnhamezustand und Polizeigewalt (Göttingen: Wallstein Verlag, 2008), pp. 168-211

Canning, K., 'Women and the Politics of Gender', in A. McElligott (ed.), Weimar Germany (Oxford: Oxford University Press, 2009), pp. 146-74

Canning, K., 'Das Geschlecht der Revolution - Stimmrecht und Staatsbürgertum 1918/19', in A. Gallus (ed.), Die vergessene Revolution von 1918/19 (Göttingen: Vandenhoeck \& Ruprecht, 2010), 84-116

Canning, K., K. Barndt and K. McGuire (eds), Weimar Publics / Weimar Subjects: Rethinking the Political Culture of Germany in the 1920s (Oxford: Berghahn, 2010)

Caplan, J., 'The Imaginary Universality of Particular Interests: The "Tradition" of the Civil Service in German History', Social History, 4 (1979), 299-317

Caplan, J., Government without Administration: State and Civil Service in Weimar and Nazi Germany (Oxford: Oxford University Press, 1988)

Carr, G. J., "“The Body Economic" in Contemporary Critiques of First World War Propaganda', Forum for Modern Language Studies, 34:4 (1998), 366-79

Chickering, R., Imperial Germany and the Great War, 1914-1918 (Cambridge: Cambridge University Press, 1998)

Chickering, R., The Great War and Urban Life in Germany: Freiburg, 1914-1918 (Cambridge: Cambridge University Press, 2007)

Chickering, R., and S. Förster (eds) Great War, Total War: Combat and 
Mobilization on the Western Front, 1914-1918 (Cambridge: Cambridge University Press, 2000)

Childers, T., 'The Social Language of Politics in Germany: The Sociology of Political Discourse in the Weimar Republic', American Historical Review, 95:2 (1990), 331-58

Clemens, B., 'Menschenrechte haben kein Geschlecht!' Zum Politikverständnis der bürgerlichen Frauenbewegung (Pfaffenweiler: Centaurus, 1988)

Crew, D. F., 'German Socialism, the State and Family Policy 1918-1933', Continuity and Change, 1 (1986), 235-62

Crew, D. F., Germans on Welfare: From Weimar to Hitler (Oxford: Oxford University Press, 1998)

Cullity, J. P., 'The Growth of Governmental Employment in Germany 1882-1950', Zeitschrift für die gesamte Staatswissenschaft, 123 (1967), $210-17$

Czarnowski, G., 'Women's Crimes, State Crimes: Abortion in Nazi Germany', in M. L. Arnot and C. Usborne (eds), Gender and Crime in Modern Europe (London: Routledge, 1999), pp. 238-56

Daniel, U., 'Fiktionen, Friktionen und Fakten - Frauenlohnarbeit im Ersten Weltkrieg', in G. Mai (ed.), Arbeiterschaft 1914-1918 in Deutschland (Düsseldorf: Droste, 1985), 277-323

Daniel, U., 'The Politics of Rationing versus the Politics of Subsistence: Working-Class Women in Germany, 1914-1918', in R. Fletcher (ed.), Bernstein to Brandt: A Short History of German Social Democracy (London: Edward Arnold, 1987), pp. 89-95

Daniel, U., 'Women's Work in Industry and Family: Germany, 1914-18', in R. Wall and J. Winter (eds), The Upheaval of War: Family, Work and Welfare in Europe, 1914-1918 (Cambridge: Cambridge University Press, 1988), pp. 267-96

Daniel, U., The War from Within: German Working-Class Women in the First World War, trans. Margaret Ries (Oxford and New York: Berg, 1997)

Davis, B., 'Food Scarcity and the Empowerment of the Female Consumer in World War 1 Berlin', in V. De Grazia and E. Furlough (eds), The Sex of Things: Gender and Consumption in Historical Perspective (Berkeley: University of California Press, 1996), pp.287-310

Davis, B., Home Fires Burning: Food, Politics, and Everyday Life in World War 1 Berlin (Chapel Hill and London: University of North Carolina Press, 2000)

Davis, B., 'Homefront: Food, Politics and Women's Everyday Life during the First World War', in K. Hagemann and S. Schüler-Springorum (eds), Home/Front The Military, War and Gender in Twentieth-Century Germany (Oxford and New York: Berg, 2002), pp.115-37 
Demm, E., 'German Teachers at War', in H. Cecil and P. Liddle (eds), Facing Armageddon: The First World War Experienced (London: Pen \& Sword Books Ltd, 1996), pp. 709-18

Dickinson, E. R., 'Biopolitics, Fascism, Democracy: Some Reflections on our Discourse about "Modernity"', Central European History, 37:1 (2004), 1-48

Dickinson, E. R., 'Policing Sex in Germany, 1882-1982: A Preliminary Statistical Analysis', Journal of the History of Sexuality, 16:2 (2007), 204-50

Dobkowski, M. N., and I. Wallmann (eds), Towards the Holocaust: The Social and Economic Collapse of the Weimar Republic (London: Greenwood Press, 1983)

Doerner, J., 'Neun Jahrzehnte Frauenbeschäftigung bei der Postverwaltung', Jahrbuch des Postwesens, 7 (1956-57), 371-402

Dollard, C., 'Marital Status and the Rhetoric of the Women's Movement in World War 1 Germany', Women in German Yearbook: Feminist Studies in German Literature and Culture, 22 (2006), 211-35

Domansky, E., 'Militarization and Reproduction in World War 1 Germany', in G. Eley (ed.), Society, Culture, and the State in Germany, 1870-1930 (Ann Arbor: University of Michigan Press, 1996), pp.427-64

Douie, V., The Professional Position of Women (London: British Federation of Business and Professional Women, 1947)

Duffy, E., 'Oskar von Miller and the Art of the Electrical Exhibition: Staffing Modernity in Weimar Germany', German History, 25:4 (2007), $517-38$

Dülffer, J., and G. Krumeich (eds), Der verlorene Frieden: Politik und Kriegskultur nach 1918 (Essen: Klartext, 2002)

Dyer, R., 'Less and More than Women and Men: Lesbian and Gay Cinema in Weimar Germany', New German Critique, 50 (1990), 5-60

Eifert, C., 'Frauenarbeit im Krieg: Die Berliner "Heimatfront" 1914-1918', Internationale wissenschaftliche Korrespondenz zur Geschichte der deutschen Arbeiterbewegung, 21:3 (September 1985), 281-95

Eifert, C., 'Coming to Terms with the State: Maternalist Politics and the Development of the Welfare State in Weimar Germany', Central European History, 30:1 (1997), 25-47

Eisenberg, C., 'Massensport in der Weimarer Republik', Archiv für Sozialgeschichte, 33 (1993), 137-77

Eley, G. (ed.), Society, Culture, and the State in Germany, 1870-1930 (Ann Arbor: University of Michigan Press, 1996)

Eley, G., and J. Palmowski (eds), Citizenship and National Identity in Twentieth-Century Germany (Stanford: Stanford University Press, 2008)

Espinaco-Virseda, A., "I feel that I belong to you”: Subculture, Die 
Freundin and Lesbian Identities in Weimar Germany', Spaces of Identity, 4:1 (2004), 83-113

Evans, R. J., The Feminist Movement in Germany, 1894-1933 (London: Sage, 1976)

Evans, R. J., 'German Women and the Triumph of Hitler', Journal of Modern History, 48:1 (1976), on-demand supplement, pp.1-53

Evans, R. J., The Feminists (London: Croom Helm, 1977)

Evans, R. J., Sozialdemokratie und Frauenemanzipation im deutschen Kaiserreich (Berlin: J. H. W. Dietz, 1979)

Evans, R. J., Comrades and Sisters: Feminism, Socialism and Pacifism in Europe 1870-1945 (Brighton: Wheatsheaf, 1987)

Evans, R. J., Rituals of Retribution: Capital Punishment in Germany 1600-1987 (Oxford: Oxford University Press, 1996)

Evans, R. J. (ed.), Society and Politics in Wilhelmine Germany (London: Croom Helm, 1978)

Evans, R. J., and D. Geary (eds), The German Unemployed: Experiences and Consequences of Mass Unemployment from the Weimar Republic to the Third Reich (London: Croom Helm, 1987)

Falter, J., Hitlers Wähler (Munich: Beck, 1991)

Falter, J., 'The Social Bases of Political Cleavages in the Weimar Republic', in L. E. Jones and J. Retallack (eds), Elections, Mass Politics, and Social Change in Modern Germany (Cambridge: Cambridge University Press, 1992), pp.371-98

Falter, J., T. Lindenberger and S. Schumann, Wablen und Abstimmungen in der Weimarer Republik: Materialien zum Wablverhalten 1919-1933 (Munich: Beck, 1986)

Feldman, G. D., The Great Disorder: Politics, Economics and Society in the German Inflation 1914-1924 (Oxford: Oxford University Press, 1993)

Feldman, G. D., Army, Industry, and Labor in Germany 1914-1918 (Princeton: Princeton University Press, 1966)

Feldman, G. D., C.-L. Holtfrerich, G. A. Ritter and P.-C. Witt (eds), Die Anpassung an die Inflation (Berlin and New York: De Gruyter, 1986)

Fell, A. S., and I. Sharp (eds), The Women's Movement in Wartime: International Perspectives, 1914-1919 (Basingstoke: Palgrave Macmillan, 2007)

Fletcher, R. (ed.), Bernstein to Brandt: A Short History of German Social Democracy (London: Edward Arnold, 1987)

Föllmer, M., 'Was Nazism Collectivistic? Redefining the Individual in Berlin, 1930-1945', Journal of Modern History, 82:1 (2010), 61-100

Föllmer, M., and R. Graf (eds), Die 'Krise' der Weimarer Republik: Zur Kritik eines Deutungsmusters (Frankfurt am Main: Campus 2005)

Förster, B., Der Königin Luise-Mythos: Mediengeschichte des 'Idealbilds deutscher Weiblichkeit’ (Göttingen: Vandenhoeck \& Ruprecht, 2011) 
Forschungsgemeinschaft 'Geschichte des Kampfes der Arbeiterklasse um die Befreiung der Frau' (ed.), Die Frau und die Gesellschaft (Leipzig: Verlag für die Frau, 1974)

Frame, L., 'Gretchen, Girl, Garçonne? Weimar Science and Popular Culture in Search of the Ideal New Woman', in K. von Ankum (ed.), Women in the Metropolis: Gender and Modernity in Weimar Culture (Berkeley: University of California Press, 1997), pp.12-40

François, A., 'From Street Walking to the Convent: Child Prostitution Cases Judged by the Juvenile Court of Brussels during World War One', in H. Jones, C. O'Brien and C. Schmidt-Supprian (eds), Untold War: New Perspectives in First World War Studies (Leiden and Boston: Brill, 2008), pp.151-77

Franzoi, B., At the Very Least She Pays the Rent: Women and German Industrialisation, 1871-1914 (London: Greenwood Press, 1985)

Frauengruppe Faschismusforschung (ed.), Mutterkreuz und Arbeitsbuch: Zur Geschichte der Franen in der Weimarer Republik und im Nationalsozialismus (Frankfurt am Main: Fischer, 1988)

Freund-Widder, M., Frauen unter Kontrolle: Prostitution und ihre staatliche Bekämpfung in Hamburg vom Ende des Kaiserreichs bis zu den Anfängen der Bundesrepublik (Münster: Lit Verlag, 2003)

Frevert, U., 'Vom Klavier zur Schreibmaschine - weiblicher Arbeitsmarkt und Rollenzuweisungen am Beispiel der weiblichen Angestellten in der Weimarer Republik', in A. Kuhn and G. Schneider (eds), Franen in der Geschichte, vol. 1 (Düsseldorf: Schwann, 1979), pp. 82-112

Frevert, U., 'Traditionale Weiblichkeit und moderne Interessenorganisation: Frauen im Angestelltenberuf 1918-1933', Geschichte und Gesellschaft, 7:3-4 (1981), 507-33

Frevert, U., 'Women Workers, Workers' Wives and Social Democracy in Imperial Germany', in R. Fletcher (ed.), Bernstein to Brandt. A Short History of German Social Democracy (London: Edward Arnold, 1987), pp.34-44

Frevert, U., Women in German History: From Bourgeois Emancipation to Sexual Liberation (Oxford: Berg, 1989)

Frieden, S., R. W. McCormick, V. P. Petersen and L. M. Vogelsang (eds), Gender and German Cinema: Feminist Interventions, vol. 2: German Film History: German History on Film (Oxford: Berg, 1993)

Friedrich, O., Beyond the Deluge: A Portrait of Berlin in the 1920s (New York: Harper and Row, 1972)

Fritzsche, P., 'Did Weimar Fail?', Journal of Modern History, 68:3 (1996), 629-56

Fritzsche, P., Germans into Nazis (Cambridge, MA: Harvard University Press, 1998)

Fritzsche, P., 'The Economy of Experience in Weimar Germany', in 
K. Canning, K. Barndt and K. McGuire (eds), Weimar Publics / Weimar Subjects: Rethinking the Political Culture of Germany in the 1920 s (Oxford: Berghahn, 2010), pp.360-82

Fritzen, F., "“Neuzeitlich Leben”: Reformhausbewegung und Moderne, 1925-1933', in M. Föllmer and R. Graf (eds), Die 'Krise' der Weimarer Republik: Zur Kritik eines Deutungsmusters (Frankfurt: Campus Verlag, 2005), pp. 165-85

Frohman, L., 'Prevention, Welfare, and Citizenship: The War on Tuberculosis and Infant Mortality in Germany, 1900-1930', Central European History, 39:3 (2006), 431-81

Frohman, L., Poor Relief and Welfare in Germany from the Reformation to World War 1 (Cambridge: Cambridge University Press, 2008)

Fromm, E., The Working Class in Weimar Germany: A Psychological and Sociological Study (London: Berg, 1984)

Frye, B. B., Liberal Democrats in the Weimar Republic: The History of the German Democratic Party and the German State Party (Carbondale: Southern Illinois University Press, 1985)

Führ, C., 'Schulpolitik im Spannungsfeld zwischen Reich und Ländern: Das Scheitern der Schulreform in der Weimarer Republik', Aus Politik und Zeitgeschichte, B 42 (1970), 3-31

Führer, K. C., 'Auf dem Weg zur "Massenkultur" ? Kino und Rundfunk in der Weimarer Republik', Historische Zeitschrift, 262:3 (1996), 739-81

Führer, K. C., 'A Medium of Modernity? Broadcasting in Weimar Germany, 1923-32', Journal of Modern History, 69:4 (1997), 722-53

Führer, K., and C. Ross (eds), Mass Media, Culture and Society in Twentieth-Century Germany (Basingstoke: Palgrave Macmillan, 2006) Fulda, B., 'Industries of Sensationalism: German Tabloids in Weimar Berlin', in in K. Führer and C. Ross (eds), Mass Media, Culture and Society in Twentieth-Century Germany (Basingstoke: Palgrave Macmillan, 2006), pp.183-203

Funke, L. (ed.), Die Liberalen: Frei sein, um andere frei zu machen (Stuttgart: Seewald, 1984)

Funkenstein, S. L., 'A Man's Place in a Woman's World: Otto Dix, Social Dancing, and Constructions of Masculinity in Weimar Germany', Women in German Yearbook: Feminist Studies in German Literature, 21 (2005), 163-91

Gabriel, N., “Nichts von diesem Kleinmut, nichts von dieser Angst”: Feminismus, Internationalismus und Pazifismus bei Anita Augspurg und Lida Gustava Heymann', Ariadne, 24 (November 1993), 60-72

Ganeva, M., 'Fashion Photography and Women's Modernity in Weimar Germany: The Case of Yva', NWSA Journal, 15:3 (2003), 1-25

Ganeva, M., Women in Weimar Fashion: Discourses and Displays in German Culture, 1918-1933 (Rochester: Camden House, 2008) 
Gersdorff, U. von, Frauen im Kriegsdienst, 1914-1945 (Stuttgart: Deutsche Verlagsanstalt, 1969)

Gersdorff, U. von, 'Frauenarbeit und Frauenemanzipation im ersten Weltkrieg', Francia, 2 (1974), 502-23

Gilbert, F., A European Past: Memoirs, 1905-1945 (New York: W. W. Norton Company, 1988)

Glass, D. V., Population Policies and Movements in Europe (London: Frank Cass \& Co. Ltd, 1967)

Goeschel, C., Suicide in Nazi Germany (Oxford: Oxford University Press, 2009)

Götze, D., 'Die organisatorische Vorbereitung für die Schaffung der kommunistischen Frauenbewegung 1919-1921', Zeitschrift für Geschichtswissenschaft, 23 (1975), 1165-76

Goodman, K., and R. H. Sanders (eds), Proceedings of the Second Annual Women in German Symposium (Oxford, OH: Miami University, 1977)

Graf, R., 'Anticipating the Future in the Present: "New Women" and Other Beings of the Future in Weimar Germany', Central European History, 42 (2009), 647-73

Graf, R., 'Either-Or: The narrative of "crisis" in Weimar Germany and its Historiography', Central European History, 43 (2010), 592-615

Grayzel, S. R., Women and the First World War (Harlow: Pearson, 2002)

Grayzel, S. R., 'The Enemy Within: The Problem of British Women's Sexuality during the First World War', in N. Dombrowski (ed.), Women and War in the Twentieth Century (New York: Garland, 1999), pp. $72-89$

Grebing, H., Frauen in der deutschen Revolution 1918/19 (Heidelberg: Stiftung Reichspräsident-Friedrich-Ebert-Gedenkstätte, 1994)

Greiling, W., 'Internationale Frauenliga für Frieden und Freiheit - Deutscher Zweig (IFFF-DZ) 1915-1933', in D. Fricke, W. Fritsch, H. Gottwald, S. Schmidt and M. Weißbecker (eds), Lexikon zur Parteiengeschichte: Die bürgerlichen und kleinbürgerlichen Parteien und Verbände in Deutschland (1789-1945), vol. 3 (Leipzig: Bibliographisches Institut, 1985), pp. 128-37

Greven-Aschoff, B., Die bürgerliche Franenbewegung in Deutschland 1894-1933 (Göttingen: Vandenhoeck \& Ruprecht, 1981)

Grossmann, A., 'Abortion and Economic Crisis: The 1931 Campaign against $\$ 218$ in Germany’, New German Critique, 14 (1978), 119-37

Grossmann, A., 'Crisis, Reaction, and Resistance: Women in Germany in the 1920s and 1930s', in A. Swerdlow and H. Lessinger (eds), Class, Race, and Sex: The Dynamics of Control (Boston: G. K. Hall \& Co., 1983), pp. 60-74

Grossmann, A., " "Satisfaction is domestic happiness”: Mass Working-Class Sex Reform Organisations in the Weimar Republic', in M. Dobkowski 
and I. Wallimann (eds), Towards the Holocaust: The Social and Economic Collapse of the Weimar Republic (Westport: Greenwood, 1983), pp.265-93

Grossmann, A., 'The New Woman and the Rationalization of Sexuality in Weimar Germany', in A. Snitow, C. Stansell and S. Thompson (eds), Desire: The Politics of Sexuality (London: Virago Press, 1984), pp. 190-208

Grossmann, A., 'Girlkultur or Thoroughly Rationalised Female: A New Woman in Weimar Germany?', in J. Friedlander, B. W. Cook, A. KesslerHarris and C. Smith-Rosenberg (eds), Women in Culture and Politics: A Century of Change (Bloomington: Indiana University Press, 1986), pp. 62-80

Grossmann, A., 'German Women Doctors from Berlin to New York: Maternity and Modernity in Weimar and in Exile', Feminist Studies, 19:1 (1993), 65-88

Grossmann, A., Reforming Sex: The German Movement for Birth Control and Abortion Reform, 1920-1950 (Oxford: Oxford University Press, 1995)

Grossmann, A., 'German Communism and New Women: Dilemmas and Contradictions', in H. Gruber and P. Graves (eds), Women and Socialism: Socialism and Women (Oxford: Berghahn, 1998), pp.133-68

Gruber, H., and P. Graves (eds), Women and Socialism: Socialism and Women (Oxford: Berghahn, 1998)

Guenther, I., Nazi Chic? Fashioning Women in the Third Reich (Oxford: Berg, 2004)

Guttsman, W. L., Workers' Culture in Weimar Germany: Between Tradition and Commitment (Oxford: Berg, 1990)

Habeth, S., 'Die Freiberuflerin und Beamtin (Ende 19. Jahrhundert bis 1945)', in H. Pohl and W. Treue (eds), Die Frau in der deutschen Wirtschaft (Wiesbaden: Franz Steiner Verlag, 1985), pp. 155-70

Hackett, A., 'The German Women's Movement and Suffrage, 1890-1914: A Study of National Feminism', in R. J. Bezucha (ed.), Modern European Social History (London: D. C. Heath \& Co., 1972), pp.356-86

Hagemann, K., "Equal but not the same”: The Social Democratic Women's Movement in the Weimar Republic', in R. Fletcher (ed.), Bernstein to Brandt: A Short History of German Social Democracy (London: Edward Arnold, 1987), pp.133-43

Hagemann, K., Frauenalltag und Männerpolitik: Alltagsleben und gesellschaftliches Handeln von Arbeiterfrauen in der Weimarer Republik (Bonn: J. H. W. Dietz, 1990)

Hagemann, K., ““... wir werden alt vom Arbeiten”: Die soziale Situation alternder Arbeiterfrauen in der Weimarer Republik am Beispiel Hamburgs', Archiv für Sozialgeschichte, 30 (1990), 247-95 
Hagemann, K., ‘Men's Demonstrations and Women's Protest: Gender in Collective Action in the Urban Working-Class Milieu in the Weimar Republic', Gender and History, 5 (1993), 101-19

Hagemann, K., 'Of “Old” and "New” Housewives: Everyday Housework and the Limits of Household Rationalisation in the Urban WorkingClass Milieu of the Weimar Republic', International Review of Social History, 41:3 (1996), 305-30

Hagemann, K., 'Rationalizing Family Work: Municipal Family Welfare and Urban Working-Class Mothers in Germany', Social Politics, 4:1 (1997), 19-48

Hagemann, K., “Jede Kraft wird gebraucht”: Militäreinsatz von Frauen im Ersten und Zweiten Weltkrieg', in B. Thoss and H.-E. Volkmann (eds), Erster Weltkrieg - Zweiter Weltkrieg: Ein Vergleich (Paderborn: Schöningh, 2002), pp. 79-106

Hagemann, K., and J. Kolossa, Gleiche Rechte - gleiche Pflichten? (Hamburg, VSA-Verlag, 1990)

Hagemann, K. (ed.), Eine Frauensache: Alltagsleben und Geburtenpolitik 1919-1933 (Pfaffenweiler: Centaurus, 1991)

Hagemann, K., and S. Schüler-Springorum (eds), Home/Front: The Military, War and Gender in Twentieth-Century Germany (Oxford and New York: Berg, 2002)

Hagenlücke, H., 'The Home Front in Germany', in J. Bourne, P. Liddle and I. Whitehead (eds), The Great World War, 1914-1945: Who Won? Who Lost? (London: HarperCollins, 2001), pp. 57-73

Hahn, C., 'Der öffentliche Dienst und die Frauen - Beamtinnen in der Weimarer Republik', in Frauengruppe Faschismusforschung (ed.), Mutterkreuz und Arbeitsbuch: Zur Geschichte der Frauen in der Weimarer Republik und im Nationalsozialismus (Frankfurt am Main: Fischer, 1988), pp.49-78

Hake, S., 'In the Mirror of Fashion', in K. von Ankum (ed.), Women in the Metropolis: Gender and Modernity in Weimar Culture (Berkeley: University of California Press, 1997), pp. 185-201

Hales, B., 'Woman as Sexual Criminal: Weimar Constructions of the Criminal Femme Fatale', Women in German Yearbook: Feminist Studies in German Literature and Culture, 12 (1996), 101-21

Hamann, B., Der Erste Weltkrieg: Wabrheit und Lüge in Bildern und Texten (Munich: Piper Verlag, 2nd edn, 2008)

Hämmerle, C., "“Wirf ihnen alles hin und schau, dass du fort kommst”: Die Feldpost eines Paares in der Geschlechter(un)ordnung des Ersten Weltkrieges', Historische Anthropologie, 6 (1998), 431-58

Hänger, A., 'Politisch oder vaterländisch? Der vaterländische Frauenverein zwischen Kaiserreich und Weimarer Republik', in E. Schöck-Quinteros and C. Streubel (eds), Ihrem Volk verantwortlich: Frauen der politischen 
Rechten (1890-1933). Organisationen - Agitationen - Ideologien (Berlin: Trafo-Verlag, 2007), pp. 57-86

Hardach, G., The First World War 1914-1918 (Berkeley: University of California Press, 1977)

Hardt, H., 'Pictures for the Masses: Photography and the Rise of Popular Magazines in the Weimar Republic', Journal of Communication Inquiry, 13:1 (1989), 7-30

Harris, V., 'In the Absence of Empire: Feminism, Abolitionism and Social Work in Hamburg (c. 1900-1933)', Women's History Review, 17:2 (2008), 279-98

Harris, V., Selling Sex in the Reich: Prostitutes in German Society, 19141945 (Oxford: Oxford University Press, 2010)

Harsch, D., German Social Democracy and the Rise of Nazism (Chapel Hill: University of North Carolina Press, 1993)

Harsch, D., 'The Iron Front: Weimar Social Democracy between Tradition and Modernity', in D. E. Barclay and E. D. Weitz (eds), Between Reform and Revolution: German Socialism and Communism from 1840 to 1990 (Oxford: Berghahn, 1998), pp. 251-73

Harvey, E., 'Private Fantasy and Public Intervention: Girls' Reading in Weimar Germany', in J. Birkett and E. Harvey (eds), Determined Women: Studies in the Construction of the Female Subject, 1900-1990 (London: Macmillan 1991), pp.38-67

Harvey, E., 'Serving the Volk, Saving the Nation: Women in the Youth Movement and Public Sphere in Weimar Germany', in L. E. Jones and J. Retallack (eds), Elections, Mass Politics and Social Change in Modern Germany (Cambridge: Cambridge University Press, 1992), pp. 201-21

Harvey, E., Youth and the Welfare State in Weimar Germany (Oxford: Clarendon Press, 1993)

Harvey, E., 'The Failure of Feminism? Young Women and the Bourgeois Feminist Movement in Weimar Germany 1918-1933', Central European History, 28:1 (1995), 1-28

Harvey, E., 'Gender, Generation and Politics: Young Protestant Women in the Final Years of the Weimar Republic', in M. Roseman (ed.), Generations in Conflict (Cambridge: Cambridge University Press, 1995), pp. 184-209

Harvey, E., 'Culture and Society in Weimar Germany: The Impact of Modernism and Mass Culture', in M. Fulbrook (ed.), German History since 1800 (London: Arnold, 1997), pp. 279-97

Harvey, E., 'Pilgrimages to the "Bleeding Border": Gender and Rituals of Nationalist Protest in Germany, 1919-39', Women's History Review, 9:2 (2000), 201-29

Harvey, E., 'Visions of the Volk: German Women and the Far Right from 
Kaiserreich to Third Reich', Journal of Women's History, 16:3 (2004), 152-67

Harvey, E., “"Ich war überall”: Die NS-Propagandaphotographin Liselotte Purpur', in S. Steinbacher (ed.), Volksgenossinnen: Franen in der NS-Volksgemeinschaft (Göttingen: Hubert \& Co., 2007), pp. 138-53

Hau, M., The Cult of Health and Beauty in Germany: A Social History, 1890-1930 (Chicago: University of Chicago Press, 2003)

Hau, M., 'Sports in the Human Economy: "Leibesübungen”, Medicine, Psychology, and Performance Enhancement during the Weimar Republic', Central European History, 41:3 (2008), 381-412

Hausen, K., 'Mothers, Sons, and the Sale of Symbols and Goods: The "German Mother's Day" 1923-33', in H. Medick and D. W. Sabean (eds), Interest and Emotion: Essays on the Study of Family and Kinship (Cambridge: Cambridge University Press, 1984), pp.371-413

Hausen, K., 'Unemployment also Hits Women: The New and the Old Woman on the Dark Side of the Golden Twenties in Germany', in P. Stachura (ed.), Unemployment and the Great Depression in Weimar Germany (Basingstoke: Macmillan, 1986), pp. 78-120

Hausen, K., 'The German Nation's Obligation to the Heroes' Widows of World War I', in M. R. Higonnet, J. Jenson, S. Michel and M. C. Weitz (eds), Behind the Lines: Gender and the Two World Wars (New Haven and London: Yale University Press, 1987), pp.126-40

Heineman, E. D., What Difference does a Husband Make? Women and Marital Status in Nazi and Postwar Germany (Berkeley: University of California Press, 1999)

Heinemann, R., Familie zwischen Tradition und Emanzipation: Katholiche und sozialdemokratische Familienkonzeptionen in der Weimarer Republik (Munich: Oldenbourg Wissenschaftliches Verlag, 2004)

Heinsohn, K., 'Germany', in K. Passmore (ed.), Women, Gender and Fascism in Europe, 1919-45 (Manchester: Manchester University Press, 2003), pp.33-56

Heinsohn, K., 'Kampf um die Wählerinnen: Die Idee der "Volksgemeinschaft" am Ende der Weimarer Republik', in S. Steinbacher (ed.), Volksgenossinnen: Frauen in der NS-Volksgemeinschaft (Göttingen: Hubert \& Co., 2007), pp. 29-47

Heinsohn, K., Konservative Parteien in Deutschland 1912 bis 1933 (Düsseldorf: Droste, 2010)

Hellwig, R. (ed.), Die Christdemokratinnen: Unterwegs zur Partnerschaft (Stuttgart: Seewald, 1984)

Hering, S., "IIch ging meinen Weg” - Erinnerungen bürgerlicher Frauenrechtlerinnen an das Jahr 1933', Ariadne, 18 (November 1990), $10-17$ 
Hering, S., Die Kriegsgewinnlerinnen: Praxis und Ideologie der deutschen Frauenbewegung im Ersten Weltkrieg (Pfaffenweiler: Centaurus, 1990)

Hering, S., 'Die Eroberung des Patriarchats? Frauenbewegung und Staat zwischen 1914 und 1920', Metis: Zeitschrift für historische Frauenforschung und feministische Praxis, 1:1 (1992), 28-41

Herrmann, U., 'Social Democratic Women in Germany and the Struggle for Peace Before and During the First World War', in R. R. Pierson (ed.), Women and Peace (Beckenham: Croom Helm,1987), pp.90-102

Herzog, T., Crime Stories: Criminalistic Fantasy and the Culture of Crisis in Weimar Germany (Oxford: Berghahn, 2009)

Heymann, L. G., and A. Augspurg, Erlebtes - Erschautes (Bodenheim: Athenaeum, 1987)

Hieber, H., "Mademoiselle Docteur": The Life and Service of Imperial Germany's Only Female Intelligence Officer', Journal of Intelligence History, 5:2 (2005), 91-108

Hofmann-Göttig, J., Emanzipation mit dem Stimmzettel: 70 Jahre Frauenwablrecht in Deutschland (Bonn: Verlag Neue Gesellschaft, 1986) Hong, Y.-S., 'The Contradictions of Modernisation in the German Welfare State: Gender and the Politics of Welfare Reform in First World War Germany', Social History, 17:2 (1992), 251-70

Hong, Y.-S., Welfare, Modernity and the Weimar State, 1919-1933 (Princeton: Princeton University Press, 1998)

Hong, Y.-S., 'The Weimar Welfare System', in A. McElligott (ed.), Weimar Germany (Oxford: Oxford University Press, 2009), pp. 175-206

Horan, G., Mothers, Warriors, Guardians of the Soul: Female Discourse in National Socialism 1924-1934 (Berlin: Walter de Gruyter, 2003)

Horne, J., 'German Atrocities, 1914: Fact, Fantasy or Fabrication', History Today, 52:4 (April 2002), 47-53

Horne, J. (ed.), A Companion to World War 1 (Oxford: Wiley-Blackwell, 2010)

Huber, A. (ed.), Die Sozialdemokratinnen: Verdient die Nachtigall Lob, wenn sie singt? (Stuttgart: Seewald Verlag, 1984)

Huerkamp, C., 'Jüdische Akademikerinnen in Deutschland 1900-1938', Geschichte und Gesellschaft, 19 (1993), 311-31

Hutton, M. J., Russian and West European Women, 1860-1939: Dreams, Struggles and Nightmares (Oxford: Rowman and Littlefield, 2001)

Imhoof, D., 'The Game of Political Change: Sports in Göttingen during the Weimar and Nazi Eras', German History, 27:3 (2009), 374-94

James, H., The German Slump: Politics and Economics 1924-1936 (Oxford: Oxford University Press, 1986)

Janusch, D., Die plakative Propaganda der Sozialdemokratischen Partei Deutschlands zu den Reichstagswablen 1928 bis 1932 (Bochum: Brockmeyer, 1989) 
Jarausch, K. H., 'The Crisis of German Professions 1918-33', Journal of Contemporary History, 20 (1985), 377-98

Jarausch, K., and L. E. Jones (eds), In Search of a Liberal Germany: Studies in the History of German Liberalism from 1789 to the Present (Oxford: Berg, 1990)

Jefferies, M., "“For a genuine and noble nakedness"? German Naturism in the Third Reich', German History, 24:1 (2006), 62-84

Jensen, E. N., Body by Weimar: Athletes, Gender, and German Modernity (Oxford: Oxford University Press, 2010)

Jerram, L., 'Kitchen Sink Dramas: Women, Modernity and Space in Weimar Germany', Cultural Geographies, 13 (2006), 538-56

Johnson, J. A., 'German Women in Chemistry, 1895-1925 (Part I)', NTM: Zeitschrift für Geschichte der Wissenschaften, Technik and Medizin, 6 (1998), 1-21, and 'German Women in Chemistry, 1925-1945 (Part II)', ibid., pp. 65-90

Jones, L. E., 'Generational Conflict and the Problem of Political Mobilization in the Weimar Republic', in L. E. Jones and J. Retallack (eds), Elections, Mass Politics and Social Change in Modern Germany (Cambridge: Cambridge University Press, 1992), pp.347-70

Jones, E. B., 'The Gendering of the Postwar Agricultural Labour Shortage in Saxony, 1918-1925', Central European History, 32:3 (1999), 311-29

Jones, E. B., 'A New Stage of Life? Young Farm Women's Changing Expectations and Aspirations about Work in Weimar Saxony', German History, 19 (2001), 549-70

Jones, E. B., 'Pre-and Post-War Generations of Rural Female Youth and the Future of the German nation, 1871-1933', Continuity and Change, 19:3 (2004), 347-65

Jones, E. B., Gender and Rural Modernity: Farm Women and the Politics of Labour in Germany, 1871-1933 (Farnham: Ashgate, 2009)

Jones, H., C. O'Brien and C. Schmidt-Supprian (eds), Untold War: New Perspectives in First World War Studies (Leiden and Boston: Brill, 2008)

Jones, L. E., 'German Conservatism at the Crossroads: Count Kuno von Westarp and the Struggle for Control of the DNVP, 1928-1930', Contemporary European History, 18:2 (2009), 147-77

Jones, L. E., and J. Retallack (eds), Elections, Mass Politics, and Social Change in Modern Germany (Cambridge: Cambridge University Press, 1992)

Kaes, A., M. Jay and E. Dimendberg (eds), The Weimar Republic Sourcebook (Berkeley: University of California Press, 1994)

Kampmann, D., “'Zölibat - ohne uns!” - die soziale Situation und politische Einstellung der Lehrerinnen in der Weimarer Republik', in Frauengruppe Faschismusforschung (ed.), Mutterkreuz und Arbeitsbuch: Zur Geschichte der Franen in der Weimarer Republik 
und im Nationalsozialismus (Frankfurt am Main: Fischer, 1988), pp. 79-104

Kater, M. H., 'Krisis des Frauenstudiums in der Weimarer Republik', Vierteljahrschrift für Sozial- und Wirtschaftsgeschichte, 59 (1972), 207-55

Kater, M. H., 'The Work Student: A Socio-Economic Phenomenon of Early Weimar Germany', Journal of Contemporary History, 10:1 (1975), 71-94

Kater, M. H., 'Frauen in der NS-Bewegung', Vierteljahrshefte für Zeitgeschichte, 31:2 (1983), 202-41

Kater, M. H., 'Professionalization and Socialization of Physicians in Wilhelmine and Weimar Germany', Journal of Contemporary History, 20 (1985), 677-701

Kerchner, B., Beruf und Geschlecht (Göttingen: Vandenhoeck \& Ruprecht, 1992)

Kershaw, I., Hitler. 1936-45: Nemesis (London: Allen Lane, 2000)

Kessemeier, G., Sportlich, sachlich, männlich: Das Bild der 'Neuen Frau' in den zwanziger Jahren (Dortmund: Edition Ebersbach, 2000)

Kleiber,L., 'Woihr seid, da soll die Sonne scheinen!'-Der Frauenarbeitsdienst am Ende der Weimarer Republik und im Nationalsozialismus', in Frauengruppe Faschismusforschung (ed.), Mutterkreuz und Arbeitsbuch: Zur Geschichte der Frauen in der Weimarer Republik und im Nationalsozialismus (Frankfurt am Main: Fischer, 1988), pp.188-214

Kniesche, T. W., and S. Brockmann (eds), Dancing on the Volcano: Essays on the Culture of the Weimar Republic (Columbia: Camden House, 1994)

Knodel, J. E., The Decline of Fertility in Germany, 1871-1939 (Princeton: Princeton University Press, 1974)

Koch, E., 'Jeder tut, was er kann fürs Vaterland: Frauen und Männer an der Heilbronner "Heimatfront", in G. Hirschfeld, G. Krumeich, D. Langewiesche and H.-P. Ullmann (eds), Kriegserfahrungen: Studien zur Sozial- und Mentalitätsgeschichte des Ersten Weltkriegs (Essen: Klartext Verlagsgesellschaft, 1997), pp. 36-52

Kohn, W. S. G., Women in National Legislatures (New York: Praeger, 1980)

Kokula, I., 'Freundinnen: Lesbische Frauen in der Weimarer Zeit', in K. von Soden, M. Schmidt, A. Delille and B. Becker (eds), Hart und Zart: Frauenleben 1920-1970 (Berlin: Elefantenpress, 1990), pp.128-32

Kontos, S., Die Partei kämpft wie ein Mann (Frankfurt am Main: Stroemfeld Verlag, 1979)

Koonz, C., 'Conflicting Allegiances: Political Ideology and Women Legislators in Weimar Germany', Signs: Journal of Women in Culture and Society, 1:3 (1976), 663-83 
Koonz, C., 'Nazi Women before 1933: Rebels against Emancipation', Social Science Quarterly, 56:4 (1976), 553-63

Koonz, C., Mothers in the Fatherland: Women, the Family and Nazi Politics (London: Jonathan Cape, 1987)

Kracauer, S., Die Angestellten (Frankfurt am Main: Suhrkamp, 2nd edn, 1974)

Kramer, A., Dynamics of Destruction: Culture and Mass Killing in the First World War (Oxford: Oxford University Press, 2007)

Kramer, H., 'Frankfurt's Working Women: Scapegoats or Winners in the Great Depression?', in R. J. Evans and D. Geary (eds), The German Unemployed: Experiences and Consequences of Mass Unemployment from the Weimar Republic to the Third Reich (London: Croom Helm, 1987), pp. 108-41

Kramer, N., Volksgenossinnen an der Heimatfront: Mobilisierung, Verhalten, Erinnerung (Göttingen: Vandenhoeck \& Ruprecht, 2011)

Kuczynski, J., Studien zur Geschichte der Lage der Arbeiterin in Deutschland von 1700 bis zur Gegenwart (Berlin: Akademie-Verlag, 2nd edn, 1965)

Kuhlman, E., Reconstructing Patriarchy after the Great War: Women, Gender, and Postwar Reconciliation between Nations (Basingstoke: Palgrave Macmillan, 2008)

Kuhlman, E., 'The "Women's International League for Peace and Freedom" and Reconciliation after the Great War', in A. S. Fell and I. Sharp (eds), The Women's Movement in Wartime: International Perspectives, 19141919 (Basingstoke: Palgrave Macmillan, 2007), pp. 227-43

Kuhlman, E., 'The Rhineland Horror Campaign and the Aftermath of War', in I. Sharp and M. Stibbe (eds), Aftermaths of War: Women's Movements and Female Activists, 1918-1923 (Leiden: Brill, 2011), pp. 89-109

Kuhn, A., and G. Schneider (eds), Frauen in der Geschichte, vol. 1 (Düsseldorf: Schwann, 1979)

Kundrus, B., Kriegerfrauen: Familienpolitik und Geschlechterverhältnisse im Ersten und Zweiten Weltkrieg (Hamburg: Christians, 1995)

Kundrus, B., 'Gender Wars: The First World War and the Construction of Gender Relations in the Weimar Republic', in K. Hagemann and S. Schüler-Springorum (eds), Home/Front: The Military, War and Gender in Twentieth-Century Germany (Oxford and New York: Berg, 2002), pp. 159-79

Kunz, A., 'Stand versus Klasse: Beamtenschaft und Gewerkschaften im Konflikt um den Personalabbau 1923/24', Geschichte und Gesellschaft, 8 (1982), 55-86

Kunz, A., Civil Servants and the Politics of Inflation in Germany, 19141924 (Berlin and New York: De Gruyter, 1986) 
Lacey, K., 'From Plauderei to Propaganda: On Women's Radio in Germany, 1924-1935', Media, Culture and Society, 16 (1994), 589-607

Lacey, K., Feminine Frequencies: Gender, German Radio, and the Public Sphere, 1923-1939 (Ann Arbor: University of Michigan Press, 1996)

Lampela, L., 'Portrait of a Lesbian Couple', Journal of Gay and Lesbian Issues in Education, 3:4 (2006), 7-10

Langstrum, J. W., 'The Display Window: Designs and Desires of Weimar Consumerism', New German Critique, 76 (1999), 115-60

Lareau, A., 'Lavender Songs: Undermining Gender in Weimar Cabaret and Beyond', Popular Music and Society, 28:1 (2005), 15-33

Lauterer, H.-M., 'Republikanerinnen des Herzens: Sozialdemokratinnen und Nation 1914-1933', in U. Planert (ed.), Nation, Politik und Geschlecht: Frauenbewegungen und Nationalismus in der Moderne (Frankfurt am Main: Campus, 2000), pp.275-91

Lauterer, H. M., Parlamentarierinnen in Deutschland 1918/19-1949 (Königstein: Ulrike Helmer Verlag, 2002)

Lavin, M., 'Androgyny, Spectatorship, and the Weimar Photomontages of Hanna Höch', New German Critique, 51 (1990), 62-86

Lavin, M., Clean New World: Culture, Politics and Graphic Design (London: MIT Press, 2001)

Lee, W. R., and E. Rosenhaft (eds), State, Social Policy and Social Change in Germany 1880-1994 (Oxford: Berg, 2nd edn, 1997)

Lewis, B. I., 'Lustmord: Inside the Windows of the Metropolis', in K. von Ankum (ed.), Women in the Metropolis: Gender and Modernity in Weimar Culture (Berkeley: University of California Press, 1997), pp. 202-32

Lilienthal, G., 'The Illegitimacy Question in Germany, 1900-1945. Areas of Tension in Social and Population Policy', Continuity and Change, 5:2 (1990), 249-81

Loewenberg, P., 'Germany, the Home Front (1): The Physical and Psychological Consequences of Home Front Hardship', in H. Cecil and P. Liddle (eds), Facing Armageddon: The First World War Experienced (London: Pen \& Sword Books Ltd, 1996)

Lüders, M.-E., Fürchte dich nicht: Persönliches und Politisches aus mehr als achtzig Jahren, 1878-1962 (Cologne: Westdeutscher Verlag, 1963)

Lummel, P., 'Food Provisioning in the German Army in the First World War', in I. Zweiniger-Bargielowska, R. Duffett and A. Drouard (eds), Food and War in Twentieth Century Europe (Farnham: Ashgate, 2011), pp. 13-25

Lybeck, M. M., 'Gender, Sexuality and Belonging: Female Homosexuality in Germany, 1890-1933', Bulletin of the German Historical Institute, 44 (2009), 29-41

Mai, G., 'Arbeitsmarktregulierung oder Sozialpolitik? Die personelle 
Demobilmachung in Deutschland 1918 bis 1920/24', in G. D. Feldman, C.-L. Holtferich, G. A. Ritter and P.-C. Witt (eds), Die Anpassung an die Inflation (Berlin and New York: De Gruyter, 1986), pp. 202-36

Makela, M., 'The Rise and Fall of the Flapper Dress: Nationalism and AntiSemitism in Early-Twentieth-Century Discourse in German Fashion', Journal of Popular Culture, 34:3 (2000), 183-208

Mason, T., 'Women in Germany, 1925-1940: Family, Welfare and Work', History Workshop, 1 (1976), 74-113; 2 (1976), 5-32

Mass, S., 'Von der "schwarzen Schmach" zur "deutschen Heimat", WerkstattGeschichte, 32 (2002), 44-57

Mazon, P. M., Gender and the Modern Research University: The Admission of Women to German Higher Education, 1865-1914 (Stanford: Stanford University Press, 2003)

McCormick, R. W., Gender and Sexuality in Weimar Modernity: Film, Literature, and New Objectivity (Basingstoke: Palgrave, 2001)

McElligott, A. (ed.), Weimar Germany (Oxford: Oxford University Press, 2009)

McIntyre, J., 'Women and the Professions in Germany, 1930-1940', in A. Nicholls and E. Matthias (eds) German Democracy and the Triumph of Hitler (London: Allen \& Unwin, 1971), pp.175-213

Meier-Scherling, A.-G., 'Die Benachteiligung der Juristin zwischen 1933 und 1945', Deutsche Richterzeitung, 53 (1975), 10-13

Mergel, T., Parlamentarische Kultur in der Weimarer Republik: Politische Kommunikation, symbolische Politik und Öffentlichkeit im Reichstag (Düsseldorf: Droste Verlag, 2002)

Mergel, T., 'High Expectations - Deep Disappointments: Structures of the public Perception of Politics in the Weimar Republic' in K. Canning, K. Barndt and K. McGuire (eds), Weimar Publics/Weimar Subjects: Rethinking the Political Culture of Germany in the 1920s (Oxford: Berghahn, 2010), pp. 192-210

Meskimmon, M., We Weren't Modern Enough: Women Artists and the Limits of German Modernism (Berkeley: University of California Press, 1999)

Meskimmon, M., and S. West, Visions of the Neue Frau: Women and the Visual Arts in Weimar Germany (Aldershot: Ashgate, 1995)

Michl, S., Im Dienste des 'Volkskörpers': Deutsche und französische Ärzte im Ersten Weltkrieg (Göttingen: Vandenhoeck \& Ruprecht, 2007)

Mogulof, M., Foiled, Hitler's Jewish Olympian: The Helene Mayer Story (Oakland: RDR Books, 2002)

Morsey, R., Die Protokolle der Reichstagsfraktion und des Fraktionsvorstandes der deutschen Zentrumspartei, 1926-1933 (Mainz: Matthias-Grünewald-Verlag, 1969)

Mouton, M., 'Rescuing Children and Policing Families: Adoption Policy 
in Weimar and Nazi Germany', Central European History, 38:4 (2005), $545-71$

Mouton, M., From Nurturing the Nation to Purifying the Volk: Weimar and Nazi Family Policy, 1918-1945 (Cambridge: Cambridge University Press, 2007)

Mühlberger, D., Hitler's Voice: The Völkischer Beobachter, 1920-1933, vol. 2: Nazi Ideology and Propaganda (Oxford: Peter Lang, 2004)

Murray, B., 'The Role of the Vamp in Weimar Cinema: An Analysis of Karl Grune's The Street (Die Straße)', in S. Frieden, R. W. McCormick, V. P. Petersen and L. M. Vogelsang (eds), Gender and German Cinema: Feminist Interventions, vol. 2: German Film History: German History on Film (Oxford: Berg, 1993), pp. 33-41

Nelson, R. L., 'German Comrades - Slavic Whores: Gender Images in the German Soldier Newspapers of the First World War', in K. Hagemann and S. Schüler-Springorum (eds), Home/Front: The Military, War and Gender in Twentieth-Century Germany (Oxford and New York: Berg, 2002), pp. 69-85

Nettl, J. P., Rosa Luxemburg (Oxford: Oxford University Press, 1966)

Niehuss, M., 'Lebensweise und Familie in der Inflationszeit', in G. D. Feldman et al. (eds), Die Anpassung an die Inflation (Berlin and New York: De Gruyter, 1986), pp.237-65

Nienhaus, U., 'Weibliche Angestellte in den USA, Frankreich und Grossbritannien 1850 bis 1930 - Arbeitsmarkt, Arbeitsplatzsituation, soziale Lage, Organisation: Ein Literaturbericht', Internationale wissenschaftliche Korrespondenz zur Geschichte der deutschen Arbeiterbewegung, 21:3 (1985), 330-53

Nienhaus, U., 'Frauen, Männer und Arbeitgeber Staat - das Beispiel der deutschen Post', Sozialwissenschaftliche Informationen, 4 (1989), pp. 237-48

Nienhaus, U., Vater Staat und seine Gehilfinnen: Die Politik mit der Franenarbeit bei der deutschen Post (1864-1945) (Frankfurt am Main: Campus Verlag, 1995)

Nienhaus, U., Nicht für eine Führungsposition geeignet: Josephine Erkens und die Anfänge weiblicher Polizei in Deutschland, 1923-1933 (Münster: Westphälisches Dampfboot, 1999)

Nolan, M., "'Housework made easy": The Taylorized Housewife in Weimar Germany's Rationalised Economy', Feminist Studies, 16:3 (1990), 549-77

Orfali, S., A Jewish Girl in the Weimar Republic (Berkeley: Ronin Publishing, 1987)

Paul, G., Aufstand der Bilder: Die NS-Propaganda vor 1933 (Bonn: Dietz, 1990)

Pauwels, J. R., Women, Nazis, and Universities: Female University Students in the Third Reich (Westport: Greenwood Press, 1984) 
Peach, M., “"Der Architekt denkt, die Hausfrau lenkt”: German Modern Architecture and the Modern Woman', German Studies Review, 18:3 (1995), 441-63

Peterson, B., 'The Politics of Working-Class Women in the Weimar Republic', Central European History, 10:2 (1977), 87-111

Petersen, V. R., Women and Modernity in Weimar Germany: Reality and its Representation in Popular Fiction (Oxford: Berghahn, 2001)

Petro, P., Joyless Streets: Women and Melodramatic Representation in Weimar Germany (Princeton: Princeton University Press, 1989)

Peukert, D., Inside Nazi Germany: Conformity, Opposition, and Racism in Everyday Life, trans. R. Deveson (London: Yale University Press, 1987)

Peukert, D., 'The Weimar Republic - Old and New Perspectives', German History, 6:2 (1988), 133-44

Peukert, D., The Weimar Republic: The Crisis of Classical Modernity, trans. R. Deveson (London: Allen Lane, 1991)

Pfister, G., 'Demands, Realities and Ambivalences - Women in the Proletarian Sports Movement in Germany (1893-1933)', Women in Sport and Physical Activity Journal, 3:2 (1994), 39-68

Pfister, G., 'Sport for Women', in R. Naul and K. Hardman (eds), Sport and Physical Education in Germany (London: Routledge, 2002), pp. 165-90

Phillips Shively, W., 'Party identification, Party Choice, and Voting Stability: The Weimar Case', American Political Science Review, 66:4 (December 1972), 1203-25

Pine, L., Education in Nazi Germany (Oxford: Berg, 2010)

Planert, U., Antifeminismus im Kaiserreich: Diskurs, soziale Formation und politische Mentalität (Göttingen: Vandenhoeck and Ruprecht, 1998)

Planert, U. (ed.), Nation, Politik und Geschlecht: Franenbewegungen und Nationalismus in der Moderne (Frankfurt am Main: Campus, 2000)

Planert, U., 'Mutter und Volk', in E. Schöck-Quinteros and C. Streubel (eds), Ihrem Volk verantwortlich: Frauen der politischen Rechten (18901933). Organisationen - Agitationen - Ideologien (Berlin: Trafo-Verlag, 2007), pp.109-30

Pohl, H., and W. Treue (eds), Die Frau in der deutschen Wirtschaft (Wiesbaden: Franz Steiner Verlag, 1985)

Pore, R., A Conflict of Interest: Women in German Social Democracy 1919-1933 (London: Greenwood Press, 1981)

Preller, L., Sozialpolitik in der Weimarer Republik (Düsseldorf: AthenäumDroste, 1978)

Prestel, C., 'The "New Jewish Woman" in Weimar Germany', in W. Benz, A. Paucker and P. Pulzer (eds) Jüdisches Leben in der Weimarer Republik / Jews in the Weimar Republic (Tübingen: Mohr Siebeck, 1998), pp. $135-58$

Quataert, J. H., 'Women's Work and Worth: The Persistence of Stereotype 
Attitudes in the German Free Trade Unions, 1890-1929', in N. C. Soldon (ed.), The World of Women's Trade Unionism (Westport: Greenwood Press, 1985), pp.93-124

Quataert, J. H., 'Women's Wartime Services under the Cross: Patriotic Communities in Germany, 1912-1918', in R. Chickering and S. Förster (eds), Great War, Total War: Combat and Mobilization on the Western Front, 1914-1918 (Cambridge: Cambridge University Press, 2000), pp. 453-83

Quataert, J. H., Staging Philanthropy: Patriotic Women and the National Imagination in Dynastic Germany, 1813-1916 (Ann Arbor: University of Michigan Press, 2001)

Ras, M. E. P. de, Body, Femininity and Nationalism: Girls in the German Youth Movement, 1900-1934 (London: Routledge, 2008)

Ray, K. R., 'Bauhaus Hausfraus: Gender Formation in Design Education', Journal of Architectural Education, 55:2 (2001), 73-80

Reagin, N. R., A German Women's Movement: Class and Gender in Hanover, 1880-1933 (Chapel Hill and London: University of North Carolina Press, 1995)

Reagin, N. R., Sweeping the German Nation: Domesticity and National Identity, 1870-1945 (Cambridge: Cambridge University Press, 2007)

Reese, D., Growing Up Female in Nazi Germany (Ann Arbor: University of Michigan Press, 2006)

Reuveni, G., 'Reading, Advertising and Consumer Culture in the Weimar Period', in K. Führer and C. Ross (eds), Mass Media, Culture and Society in Twentieth-Century Germany (Basingstoke: Palgrave Macmillan, 2006), pp. 204-16

Reuveni, G., Reading Germany: Literature and Consumer Culture in Germany before 1933 (Oxford: Berghahn, 2006)

Rich, B. B., 'From Repressive Tolerance to Erotic Liberation: Girls in Uniform (Mädchen in Uniform)', in S. Frieden, R. W. McCormick, V. P. Petersen and L. M. Vogelsang (eds), Gender and German Cinema: Feminist Interventions, vol. 2: German Film History: German History on Film (Oxford: Berg, 1993), pp. 61-96

Rigby, I. K., 'German Expressionist Political Posters 1918-1919 - Art and Politics: A Failed Alliance', Art Journal, 44:1 (1984), 33-9

Roos, J., 'Backlash against Prostitutes' Rights: Origins and Dynamics of Nazi Prostitution Policies', in D. Herzog (ed.), Sexuality and German Fascism (Oxford: Berghahn, 2005), pp. 67-94

Roos, J., 'Women's Rights, Nationalist Anxiety and the "Moral” Agenda in the Early Weimar Republic: Revisiting the "Black Horror" Campaign against France's African Occupation Troops', Central European History, 42:3 (2009), 473-508

Roos, J., Weimar through the Lens of Gender: Prostitution Reform, 
Women's Emancipation, and German Democracy, 1919-33 (Ann Arbor: University of Michigan Press, 2010)

Roos, J., 'Nationalism, Racism and Propaganda in Early Weimar Germany: Contradictions in the Campaign against the "Black Horror on the Rhine", German History, 30:1 (2012), 45-74

Roseman, M. (ed.), Generations in Conflict: Youth Revolt and Generation Formation in Germany 1770-1968 (Cambridge: Cambridge University Press, 1995)

Rosenhaft, E., 'Women, Gender, and the Limits of Political History in the Age of "Mass" Politics', in L. E. Jones and J. Retallack (eds), Elections, Mass Politics and Social Change in Modern Germany (Cambridge: Cambridge University Press, 1992), pp.149-73

Rosenhaft, E., 'Restoring Moral Order on the Home Front. Compulsory Savings Plans for Young Workers in Germany, 1916-19', in F. Coetzee and M. Sherin-Coetzee, Authority, Identity and the Social History of the Great War (Oxford: Berghahn, 1995), pp. 81-112

Ross, C., 'Visions of Prosperity: The Americanisation of Advertising in Interwar Germany', in P. E. Swett, S. J. Wiesen and J. R. Zatlin (eds), Selling Modernity: Advertising in Twentieth-Century Germany (London: Duke University Press, 2007), pp. 52-77

Ross, C., Media and the Making of Modern Germany (Oxford: Oxford University Press, 2008)

Ross, C., 'Cinema, Radio, and "Mass Culture" in the Weimar Republic: Between Shared Experience and Social Division', in J. A. Williams (ed.), Weimar Culture Revisited (Basingstoke: Palgrave Macmillan, 2011), pp. 23-48

Rouette, S., “"Gleichberechtigung" ohne "Recht auf Arbeit": Demobilmachung der Frauenarbeit nach dem Ersten Weltkrieg', in C. Eifert and S. Rouette (eds), Unter allen Umständen: Frauengeschichte(n) in Berlin (Berlin: Rotation, 1986), pp.159-82

Rouette, S., Sozialpolitik als Geschlechterpolitik: Die Regulierung der Frauenarbeit nach dem Ersten Weltkrieg (Frankfurt am Main: Campus Verlag, 1993)

Rouette, S., 'Mothers and Citizens: Gender and Social Policy in Germany after the First World War', Central European History, 30:1 (1997), 48-66

Rowold, K., The Educated Woman: Minds, Bodies, and Women's Higher Education in Britain, Germany, and Spain, 1865-1914 (London: Routledge, 2010)

Rowe, D., Representing Berlin: Sexuality and the City in Imperial and Weimar Germany (Aldershot: Ashgate, 2003)

Rupp, L., 'Constructing Internationalism: The Case of Transnational Women's Organisations, 1888-1945', American Historical Review, 99:5 (December 1994), 1571-1600 
Sachsse, C., 'Social Mothers: The Bourgeois Women's Movement and German Welfare-State Formation, 1890-1929', in S. Koven and S. Michel (eds), Mothers of a New World: Maternalist Politics and the Origins of Welfare States (London: Routledge, 1993), pp.136-58

Sack, B., 'Katholismus und Nation: Der katholische Frauenbund', in U. Planert (ed.), Nation, Politik und Geschlecht: Frauenbewegungen und Nationalismus in der Moderne (Frankfurt am Main: Campus, 2000), pp. 292-308

Saldern, A. von, 'Social Rationalization of Living and Housework in Germany and the United States in the 1920s', History of the Family, 2:1 (1997), 73-93

Saldern, A. von, 'Modernization as Challenge: Perceptions and Reactions of German Social Democratic Women', in H. Gruber and P. Graves (eds), Women and Socialism: Socialism and Women (Oxford: Berghahn, 1998), pp.95-134

Saldern, A. von, The Challenge of Modernity: German Social and Cultural Studies, 1890-1960 (Ann Arbor: University of Michigan Press, 2002)

Saldern, A. von, “"Neues Wohnen”: Housing and Reform', in A. McElligott (ed.), Weimar Germany (Oxford: Oxford University Press, 2009), pp. 207-33

Sauerteig, L. D. H., “"The Fatherland is in danger, save the Fatherland": Venereal Disease, Sexuality and Gender in Imperial and Weimar Germany', in R. Davidson and L. A. Hall (eds), Sex, Sin and Suffering: Venereal Disease and European Society since 1870 (London: Routledge, 2001), pp. 76-92

Sawahn, A., Die Frauenlobby vom Land: Die Landfrauenbewegung in Deutschland und ibre Funktionärinnen 1898 bis 1948 (Frankfurt am Main: DLG Verlag, 2009)

Schaser, A., 'Bürgerliche Frauen auf dem Weg in die linksliberalen Parteien (1908-1933)', Historische Zeitschrift, 263:3 (1996), 641-80

Schaser, A., Helene Lange und Gertrud Bäumer: Eine politische Lebensgemeinschaft (Cologne: Böhlau Verlag, 2000)

Schaser, A., 'Women in a Nation of Men: The Politics of the League of German Women's Associations (BDF) in Imperial Germany', in I. Blom, K. Hagemann and C. Hall (eds), Gendered Nations: Nationalisms and Gender Order in the Long Nineteenth Century (Oxford: Berg, 2000), pp. 249-68

Scheck, R., 'German Conservatism and Female Political Activism in the Early Weimar Republic', German History, 15:1 (1997), 34-55

Scheck, R., 'Women against Versailles: Maternalism and Nationalism of Female Bourgeois Politicians in the Early Weimar Republic', German Studies Review, 2:1 (February 1999), 21-42

Scheck, R., 'Zwischen Volksgemeinschaft und Frauenrechten: Das 
Verhältnis rechtsbürgerlicher Politikerinnen zur NSDAP 1930-1933', in U. Planert (ed.) Nation, Politik und Geschlecht: Frauenbewegungen und Nationalismus in der Moderne (Frankfurt am Main: Campus, 2000), pp. 234-53

Scheck, R., 'Women on the Weimar Right: The Role of Female Politicians in the Deutschnationale Volkspartei (DNVP)', Journal of Contemporary History, 36:4 (2001), 547-60

Scheck, R., 'Wahrung des Burgfriedens: Die Wirkung des Ersten Weltkrieges auf die bürgerliche Frauenbewegung der Weimarer Republik', in J. Dülffer and G. Krumeich (eds), Der verlorene Frieden. Politik und Kriegskultur nach 1918 (Essen: Klartext, 2002), pp. 215-28

Scheck, R., 'Women in the Non-Nazi Right during the Weimar Republic: The German Nationalist People's Party (DNVP)', in P. Bacchetta and M. Power (eds), Right-Wing Women: From Conservatives to Extremists around the World (London: Routledge, 2002), pp. 141-53

Scheck, R., Mothers of the Nation: Right-Wing Women in Weimar Germany (Oxford: Berg, 2004)

Scheck, R., 'Die Partei als Heim und Familie. Frauen in den Ortsvereinen der Deutschnationalen Volkspartei und der Deutschen Volkspartei in der Weimarer Republik', in E. Schöck-Quinteros and C. Streubel (eds), Ihrem Volk verantwortlich: Frauen der politischen Rechten (18901933). Organisationen - Agitationen - Ideologien (Berlin: Trafo-Verlag, 2007), pp.153-75

Schöck-Quinteros, E., 'Der Bund Königin Luise: “Unser Kampfplatz ist die Familie", in E. Schöck-Quinteros and C. Streubel (eds), Ihrem Volk verantwortlich: Frauen der politischen Rechten (1890-1933). Organisationen - Agitationen - Ideologien (Berlin: Trafo-Verlag, 2007), pp. 231-70

Schöck-Quinteros, E., and C. Streubel (eds), Ihrem Volk verantwortlich: Frauen der politischen Rechten (1890-1933). Organisationen Agitationen - Ideologien (Berlin: Trafo-Verlag, 2007)

Schoenbaum, D., Hitler's Social Revolution: Class and Status in Nazi Germany 1933-1939 (London: Weidenfeld and Nicolson, 1967)

Schönberger, B., 'Motherly Heroines and Adventurous Girls: Red Cross Nurses and Women Army Auxiliaries in the First World War', in K. Hagemann and S. Schüler-Springorum (eds), Home/Front: The Military, War and Gender in Twentieth-Century Germany (Oxford and New York: Berg, 2002), pp. 87-113

Schoppmann, C., Days of Masquerade: Life Stories of Lesbians during the Third Reich, trans. A. Brown (New York: Columbia University Press, 1996)

Schulte, R., 'The Sick Warrior's Sister: Nursing during the First World War', in L. Abrams and E. Harvey (eds), Gender Relations in German 
History: Power, Agency and Experience from the Sixteenth Century to the Twentieth (London: UCL Press, 1996), pp. 121-41

Schulz, G., 'Die weiblichen Angestellten vom 19. Jahrhundert bis 1945', in H. Pohl and W. Treue (eds), Die Frau in der deutschen Wirtschaft (Wiesbaden: Franz Steiner Verlag,1985), pp.179-215

Schwarz, M., MdR. Biographisches Handbuch der Reichstage (Hanover: Verlag für Literatur und Zeitgeschehen, 1965)

Seipp, A. R., The Ordeal of Peace: Demobilisation and the Urban Experience in Britain and Germany, 1917-1921 (Farnham: Ashgate, 2009)

Sender, T., The Autobiography of a German Rebel (London: Labour Book Service, 1940)

Sharp, I., 'Riding the Tiger: Ambivalent Images of the New Woman in the Popular Press of the Weimar Republic', in A. Heilmann and M. Beetham (eds), New Woman Hybridities: Femininity, Feminism and International Consumer Culture, 1880-1930 (London: Routledge, 2004), pp. 118-41

Sharp, I., 'Blaming the Women: Women's "Responsibility" for the First World War', in A. S. Fell and I. Sharp (eds), The Women's Movement in Wartime: International Perspectives, 1914-1919 (Basingstoke: Palgrave Macmillan, 2007), pp.67-87

Sharp, I., 'The Disappearing Surplus: The Spinster in the Post-War Debate in Weimar Germany, 1918-1920', in Sharp I. and M. Stibbe (eds) Aftermaths of War: Women's Movements and Female Activists, 19181923 (Leiden: Brill, 2011), pp. 135-57

Sharp I., and M. Stibbe (eds), Aftermaths of War: Women's Movements and Female Activists, 1918-1923 (Leiden: Brill, 2011)

Siebrecht, C., 'Martial Spirit and Mobilisation Myths: Bourgeois Women and the "Ideas of 1914" in Germany', in A. S. Fell and I. Sharp (eds), The Women's Movement in Wartime: International Perspectives, 1914-1919 (Basingstoke: Palgrave Macmillan, 2007), pp.38-52

Siebrecht, C., 'The Mater Dolorosa on the Battlefield - Mourning Mothers in German Women's Art of the First World War', in H. Jones, C. O'Brien and C. Schmidt-Supprian (eds), Untold War: New Perspectives in First World War Studies (Leiden and Boston: Brill, 2008), pp.259-91

Siemens, D., 'Explaining Crime: Berlin Newspapers and the Construction of the Criminal in Weimar Germany', Journal of European Studies, 39:3 (2009), 336-52

Smaldone, W., Confronting Hitler: German Social Democrats in Defense of the Weimar Republic, 1929-1933 (Lanham: Lexington Books, 2010) Smith, J. S., 'Working Girls: White-Collar Workers and Prostitutes in late Weimar fiction', German Quarterly, 81:4 (2008), 449-70

Sneeringer, J., Winning Women's Votes: Propaganda and Politics in 
Weimar Germany (Chapel Hill: University of North Carolina Press, 2002)

Sneeringer, J., 'The Shopper as Voter: Women, Advertising, and Politics in Post-Inflation Germany', German Studies Review, 27:3 (2004), 475-501

Sneeringer, J., “"Frauen an die Front!” The Language of "Kampf” in DNVP Women's Propaganda 1918-33', in E. Schöck-Quinteros and C. Streubel (eds), Ihrem Volk verantwortlich: Frauen der politischen Rechten (18901933). Organisationen - Agitationen - Ideologien (Berlin: Trafo-Verlag, 2007), pp. 177-98

Soden, K. von, Die Sexualberatungsstellen der Weimarer Republik, 1919_ 1933 (Berlin: Druckhaus Hentrich Verlag, 1988)

Soden, K. von, and G. Zipfel, Siebzig Jahre Frauenstudium: Frauen in der Wissenschaft (Cologne: Pahl-Rugenstein, 1979)

Soden, K. von, M. Schmidt, A. Delille and B. Becker (eds), Hart und Zart: Frauenleben 1920-1970 (Berlin: Elefantenpress, 1990)

Søland, B., Becoming Modern: Young Women and the Reconstruction of Womanhood in the 1920s (Princeton: Princeton University Press, 2000)

Stachura, P. (ed.), Unemployment and the Great Depression in Weimar Germany (Basingstoke: Macmillan, 1986)

Stahl, G., 'Von der Hauswirtschaft zum Haushalt oder wie man vom Haus zur Wohnung kommt', in Neue Gesellschaft für Bildende Kunst (ed.), Wem gehört die Welt: Kunst und Gesellschaft in der Weimarer Republik (Berlin: Neue Gesellschaft für Bildende Kunst, 1977), pp. 87-108

Stanley, A. C., Modernising Tradition: Gender and Consumerism in Interwar France and Germany (Baton Rouge: Louisiana State University Press, 2008)

Statistisches Bundesamt (ed.), Statistisches Jahrbuch für die Bundesrepublik Deutschland 1972 (Stuttgart: W. Kohlhammer GmbH, 1973)

Statistisches Bundesamt (ed.) Statistisches Jabrbuch 1981 für die Bundesrepublik Deutschland (Stuttgart: W. Kohlhammer GmbH, 1981)

Steinbacher, S., 'Differenz der Geschlechter? Chancen und Schranken für die "Volksgenossinnen"', in F. Bajohr and M. Wildt (eds), Volksgemeinschaft: Neue Forschungen zur Gesellschaft des Nationalsozialismus (Frankfurt am Main: S. Fischer Verlag, 2009), 94-104

Steinbacher, S. (ed.), Volksgenossinen: Frauen in der NS-Volksgemeinschaft (Göttingen: Hubert \& Co., 2007)

Stephenson, J., 'Girls' Higher Education in Germany in the 1930s', Journal of Contemporary History, 10:1 (1975), 41-69

Stephenson, J., Women in Nazi Society (London: Croom Helm, 1975)

Stephenson, J., The Nazi Organisation of Women (London: Croom Helm, 1981) 
Stephenson, J., 'National Socialism and Women before 1933', in P. D. Stachura (ed.), The Nazi Machtergreifung (London: Allen and Unwin, 1983), pp. 33-48

Stephenson, J., 'Women and the Professions in Germany, 1900-1945', in G. Cocks and K. H. Jarausch (eds), German Professions, 1800-1950 (Oxford: Oxford University Press, 1990), pp. 270-88

Stephenson, J., 'Modernization, Emancipation, Mobilization: Nazi Society Reconsidered', in L. E. Jones and J. Retallack (eds), Elections, Mass Politics and Social Change in Modern Germany (Cambridge: Cambridge University Press, 1992), pp. 223-43

Stephenson, J., Women in Nazi Germany (Harlow: Longman, 2001)

Sternsdorf-Hauck, C., Brotmarken und rote Fabnen: Frauen in der bayerischen Revolution und Räterepublik 1918/19 (Cologne: Neuer ISP Verlag, 2008)

Stibbe, M., 'Anti-Feminism, Nationalism and the German Right, 19141920: A Re-Appraisal', German History, 20:2 (2002), 185-210

Stibbe, M., Women in the Third Reich (London: Arnold, 2003)

Stibbe, M., Germany 1914-1933: Politics, Society and Culture (Harlow: Pearson, 2010)

Stöckel, S., 'Infant Mortality and Concepts of Hygiene: Strategies and Consequences in the Kaiserreich and the Weimar Republic. The Example of Berlin', History of the Family, 7 (2002), 601-16

Stokes, P. R., 'Pathology, Danger and Power: Women's and Physicians' Views of Pregnancy and Childbirth in Weimar Germany', Social History of Medicine, 13:3 (2000), 359-80

Storer, C., 'Weimar Germany as Seen by an Englishwoman: British Women Writers and the Weimar Republic', German Studies Review, 32:1 (2009), 129-47

Stratigakos, D., 'The Professional Spoils of War: German Women Architects and World War 1', Journal of the Society of Architectural Historians, 66:4 (2007), 464-75

Streubel, C., 'Frauen der politischen Rechten in Kaiserreich und Republik', Historical Social Research, 28:4 (2003), 103-66

Streubel, C., Radikale Nationalistinnen: Agitation und Programmatik rechter Frauen in der Weimarer Republik (Frankfurt am Main: Campus Verlag, 2006)

Streubel, C., “"Meine Herren und Damen!” Rednerinnen der deutschnationalen Fraktion im Parlament der Weimarer Republik', in D. Boschoff and M. Wanger-Egelhaaf (eds), Mitsprache, Rederecht, Stimmgewalt: Genderkritische Strategien und Transformationen der Rhetorik (Heidelberg: Universitätsverlag Winter, 2006), pp.113-42

Streubel, C., 'Forschungen zur politischen Rechten', in E. Schöck-Quinteros and C. Streubel (eds), Ihrem Volk verantwortlich: Frauen der politischen 
Rechten (1890-1933). Organisationen - Agitationen - Ideologien (Berlin: Trafo-Verlag, 2007), pp.9-95

Streubel, C., 'Raps across the Knuckles: The Extension of War Culture by Radical Nationalist Women Journalists in Post-1918 Germany', in I. Sharp and M. Stibbe (eds), Aftermaths of War: Women's Movements and Female Activists, 1918-1923 (Leiden: Brill, 2011), pp.69-88

Süchting-Hänger, A., 'Die Anti-Versailles-Propaganda konservativer Frauen in der Weimarer Republik - eine weibliche Dankschuld?', in G. Krumeich (ed.), Versailles 1919: Ziele - Wirkung - Wabrnehmung (Essen: Klartext Verlag, 2001), pp.302-13

Süchting-Hänger, A., Das 'Gewissen der Nation': Nationales Engagement und politisches Handeln konservativer Frauenorganisationen 1900 bis 1937 (Düsseldorf: Droste Verlag, 2002)

Sutton, K., 'The Masculinized Female Athlete in Weimar Germany', German Politics and Society, 27:3 (2009), 28-49

Sutton, K., The Masculine Woman in Weimar Germany (Oxford: Berghahn, 2011)

Swett, P. E., Neighbors and Enemies: The Culture of Radicalism in Berlin, 1929-1933 (Cambridge: Cambridge University Press, 2004)

Tamagne, F., A History of Homosexuality in Europe: Berlin, London, Paris 1919-1939, vol. 1 (New York: Algora Publishing, 2004)

Tatar, M., Lustmord: Sexual Murder in Weimar Germany (Princeton: Princeton University Press, 1995)

Teuteberg, H.-J., 'Food Provisioning on the German Home Front, 19141918', in I. Zweiniger-Bargielowska, R. Duffett and A. Drouard (eds), Food and War in Twentieth Century Europe (Farnham: Ashgate, 2011), pp. 59-72

Thönnessen, W., The Emancipation of Women: Germany 1863-1933 (London: Pluto Press, 1973)

Timm, A. F., The Politics of Fertility in Twentieth-Century Berlin (Cambridge: Cambridge University Press, 2010)

Tingsten, H., Political Behaviour: Studies in Election Statistics (London: P. S. King \& Son, 1937)

Tobin, E. H., 'War and the Working Class: The Case of Düsseldorf 19141918', Central European History, 13:3-4 (1985), 257-98

Todd, L. M., “"The Soldier's Wife who Ran away with the Russian”: Sexual Infidelities in World War 1 Germany', Central European History, 44 (2011), 257-78

Usborne, C., 'Abtreibung: Mord, Therapie oder weibliches Selbstbestimmungsrecht? Der $\$ 218$ im medizinischen Diskurs der Weimarer Republik', in J. Geyer-Kordesch and A. Kuhn (eds), Frauenkörper, Medizin, Sexualität (Düsseldorf: Patmos, 1986), pp. 192-236 
Usborne, C., 'The Christian Churches and the Regulation of Sexuality in Weimar Germany', in J. Obelkevich, L. Roper and R. Samuel (eds), Disciplines of Faith: Studies in Religion, Politics and Patriarchy (London: Routledge and Kegan Paul, 1987), pp.99-112

Usborne, C., 'Pregnancy is the Woman's Active Service: Pronatalism in Germany during the First World War', in R. Wall and J. Winter (eds), The Upheaval of War: Family, Work and Welfare in Europe, 1914-1918 (Cambridge: Cambridge University Press, 1988), pp.389-416

Usborne, C., 'Abortion in Weimar Germany - the Debate amongst the Medical Profession', Continuity and Change, 5:2 (1990), 199-224

Usborne, C., The Politics of the Body in Weimar Germany (Basingstoke: Macmillan, 1992)

Usborne, C., 'The New Woman and Generational Conflict: Perceptions of Young Women's Sexual Mores in the Weimar Republic', in M. Roseman (ed.), Generations in Conflict: Youth Revolt and Generation Formation in Germany 1770-1968 (Cambridge: Cambridge University Press, 1995), pp. 137-63

Usborne, C., 'Rhetoric and Resistance: Rationalisation of Reproduction in Weimar Germany', Social Politics, 4:1 (1997), 65-89

Usborne, C., 'Abortion for Sale! The Competition between Quacks and Doctors in Weimar Germany', in M. Gijswijt-Hofstra, H. Marland and H. De Wardt (eds), Illness and Healing Alternatives in Western Europe (London: Routledge, 1997), pp. 183-204

Usborne, C., 'Representation of Abortion in Popular Culture in Weimar Germany', in P. Pasteur, N. Niederacher and M. Mesner (eds), Sexualität, Unterschichtenmilieus und ArbeiterInnenbewegung (Leipzig: Akademische Verlagsanstalt, 2003), pp. 81-92

Usborne, C., 'Rebellious Girls and Pitiable Women: Abortion Narratives in Weimar Popular Culture', German History, 23 (2005), 321-38

Usborne, C., Cultures of Abortion in Weimar Germany (Oxford: Berghahn, 2007)

Usborne, C., 'Body Biological to Body Politic', in G. Eley and J. Palmowski (eds), Citizenship and National Identity in Twentieth-Century Germany (Stanford: Stanford University Press, 2008), pp. 129-45

Vaizey, H., Surviving Hitler's War: Family Life in Germany, 1939-48 (London: Palgrave Macmillan, 2010)

Verhey, J., The Spirit of 1914: Militarism, Myth and Mobilization in Germany (Cambridge: Cambridge University Press, 2000)

Wall, R., and J. Winter (eds), The Upheaval of War: Family, Work and Welfare in Europe, 1914-1918 (Cambridge: Cambridge University Press, 1988)

Walle, M., 'Die Heimatchronik Gertrud Bäumers als weibliches Nationalepos', Ariadne, 24 (1993), 17-21 
Ward, J., Weimar Surfaces: Urban Visual Culture in 1920s Germany (Berkeley: University of California Press, 2001)

Watson, A., Enduring the Great War: Combat, Morale and Collapse in the German and British Armies, 1914-1918 (Cambridge: Cambridge University Press, 2008)

Weber, H., Die Wandlung des deutschen Kommunismus (Frankfurt am Main: Europäische Verlagsanstalt, 1969)

Weberling, A., Zwischen Räten und Parteien: Franenbewegung in Deutschland 1918/1919 (Centaurus, Pfaffenweiler, 1994)

Wehler, H.-U., The German Empire 1871-1918 (Leamington Spa: Berg, 1985)

Weill, C., 'Women in the German Revolution: Rosa Luxemburg and the Workers' Councils', in C. Fauré (ed.), Political and Historical Encyclopaedia of Women (London: Fitzroy Dearborn, 2003), pp. 412-23

Weindling, P., 'The Medical Profession, Social Hygiene and the Birth Rate in Germany, 1914-1918', in R. Wall and J. Winter (eds), The Upheaval of War: Family, Work and Welfare in Europe, 1914-1918 (Cambridge: Cambridge University Press, 1988), pp.417-37

Weindling, P., Health, Race and German Politics between National Unification and Nazism, 1870-1945 (Cambridge: Cambridge University Press, 1989)

Weindling, P., 'Eugenics and the Welfare State during the Weimar Republic', in W. R. Lee and E. Rosenhaft (eds), State, Social Policy and Social Change in Germany 1880-1994 (Oxford: Berg, 2nd edn, 1997), pp.134-63

Weitz, E. D., Creating German Communism, 1890-1990: From Popular Protests to Socialist State (Princeton: Princeton University Press, 1996)

Weitz, E. D., 'The Heroic Man and the Ever-Changing Woman: Gender and Politics in European Communism, 1917-1950', in L. L. Frader and S. O. Rose (eds), Gender and Class in Modern Europe (Ithaca: Cornell University Press, 1996), pp.311-52

Weitz, E. D., Weimar Germany: Promise and Tragedy (Princeton: Princeton University Press, 2007)

Weitz, E. D., 'Weimar Germany and the Dilemmas of Liberty', in J. C. Friedman (ed.), The Routledge History of the Holocaust (London: Routledge, 2010), pp. 59-68

Welch, D., Germany, Propaganda and Total War 1914-1918 (London: Athlone Press, 2000)

Welch, D., The Third Reich: Politics and Propaganda (London: Routledge, 2nd edn, 2002)

Wellner, G., 'Industriearbeiterinnen in der Weimarer Republik: Arbeitsmarkt, Arbeit und Privatleben 1919-1933', Geschichte und Gesellschaft, 7 (1981), 534-54 
Wenzel, G., 'Schöneberg voran! An der Front der Tod, in der Heimat die Not', in Berliner Gewerkstatt e.V. (ed.), August 1914: Ein Volk zieht in den Krieg (Berlin: Nishen, 1989), pp.158-71

Weyrather, I., Mutterkreuz und Muttertag: Der Kult um die 'deutsche Mutter' im Nationalsozialismus (Frankfurt am Main: Fischer Taschenbuch Verlag, 1993)

Whalen, R., Bitter Wounds: German Victims of the Great War, 1914-1939 (Ithaca, NY: Cornell University Press, 1984)

Wheeler, R. F., 'German Women and the Communist International: The Case of the Independent Social Democrats', Central European History, 8:2 (1975), 113-39

Wickert, C., B. Hamburger and M. Lienau, 'Helene Stöcker and the Bund für Mutterschutz', Women's Studies International Forum, 5:6 (1982), 611-18

Widdig, B., Culture and Inflation in Weimar Germany (Berkeley: University of California Press, 2001)

Wigger, I., " Black Shame" - the Campaign against "Racial Degeneration" and Female Degradation in Interwar Europe', Race and Class, 51:3 (2010), 33-46

Williams, J. A. (ed.), Weimar Culture Revisited (Basingstoke: Palgrave Macmillan, 2011)

Winter, J., 'Demography', in J. Horne (ed.), A Companion to World War 1 (Oxford: Wiley-Blackwell, 2010), pp.248-62

Winter, J., and J.-L. Robert (eds), Capital Cities at War: Paris, London, Berlin 1914-1919 (Cambridge: Cambridge University Press, 1997)

Winter, J., and J. Cole, 'Fluctuations in Infant Mortality Rates in Berlin During and After the First World War', European Journal of Population, 9 (1993), 235-63

Wittmann, I., "Echte Weiblichkeit ist ein Dienen" - die Hausgehilfin in der Weimarer Republik und im Nationalsozialismus', in Frauengruppe Faschismusforschung (ed.), Mutterkreuzund Arbeitsbuch:Zur Geschichte der Franen in der Weimarer Republik und im Nationalsozialismus (Frankfurt am Main: Fischer, 1988), pp.15-48

Wittmann, R., Geschichte des deutschen Buchhandels (Munich: Verlag C. H. Beck, 1999)

Woodfin, C. G., 'Reluctant Democrats: The Protestant Women's Auxiliary and the German National Assembly Election of 1919', Journal of the Historical Society, 4:1 (2004), 71-112

Woycke, J., Birth Control in Germany 1871-1933 (London: Routledge, 1988)

Wurms, R., “"Krieg dem Krieg” - "Dienst am Vaterland”: Frauenbewegung im Ersten Weltkrieg', in F. Herve (ed.), Geschichte der deutschen Frauenbewegung (Bonn: Pahl-Rugenstein, 1982), pp. 84-118 
Zagula, J. T., 'Saints, Sinners and Society: Images of Woman in Film and Drama, from Weimar to Hitler', Women's Studies, 19 (1991), 55-77

Zahn-Harnack, A., von, Schriften und Reden (Tübingen: Hopfer, 1964)

Ziemann, B., 'Germany after the First World War - a Violent Society? Results and Implications of Recent Research on Weimar Germany', Journal of Modern European History, 1 (2003), 580-95

Ziemann, B., 'Geschlechterbeziehungen in deutschen Feldpostbriefen des Ersten Weltkreiges', in C. Hämmerle and E. Saurer (eds), Briefkulturen und ihr Geschlecht: Zur Geschichte der privaten Korrespondenz vom 16. Jahrhundert bis heute (Vienna: Böhlau Verlag, 2003), pp. 261-82

Ziemann, B., War Experiences in Rural Germany, 1914-1923 (Oxford: Berg, 2007)

Ziemann, B., 'Weimar was Weimar: Politics, Culture and the Emplotment of the German Republic', German History, 28:4 (2010), 542-71

Ziemann, B., 'Germany 1914-1918: Total War as a Catalyst of Change', in H. W. Smith (ed.), The Oxford Handbook of Modern German History (Oxford: Oxford University Press, 2011), pp.378-99

Zimmeck, M., 'Strategies and Stratagems for the Employment of Women in the British Civil Service, 1919-1931', Historical Journal, 27 (1984), 901-24

Zweiniger-Bargielowska, I., R. Duffett and A. Drouard (eds), Food and War in Twentieth Century Europe (Farnham: Ashgate, 2011)

\section{Dissertations}

Baldauf, E., 'Die Frauenarbeit in der Landwirtschaft' (PhD dissertation, University of Kiel, 1929)

Boyd, C. E., “"Nationaler Frauendienst”: German Middle-Class Women in Service to the Fatherland, 1914-1918' (PhD dissertation, University of Georgia, 1979)

Disko, S., 'Men, Motorcycles and Modernity: Motorisation during the Weimar Republic' (PhD dissertation, New York University, 2008)

Fessenden, P. L., 'The Role of Women Deputies in the German National Constituent Assembly and the Reichstag, 1919-1933' (PhD dissertation, Ohio State University, 1976)

Hackett, A. K., 'The Politics of Feminism in Wilhelmine Germany, 18901918' (PhD dissertation, Columbia University, 1976)

Honeycutt, K., 'Clara Zetkin: A Left-Wing Socialist and Feminist in Wilhelmian Germany’ (PhD dissertation, Columbia University, 1975)

Jehle, W., 'Die Arbeiterlöhne in der Badischen Textilindustrie seit der Stabilisierung der Mark (1923-1933)' (PhD dissertation, University of Heidelberg, 1935)

Koch, S. H., 'Militärpolitik im "Jahr der Frau": Die Öffnung der 
Bundeswehr für weibliche Sanitätsoffiziere und ihre Folgen' (PhD dissertation, University of Brunswick, 2008)

Lowitsch, V., 'Die Frau als Richter' (PhD dissertation, University of Freiburg im Breisgau, 1933)

Lynn, J. M., 'Contesting Images: Representations of the Modern Woman in the German Illustrated Press, 1924-1933' (MA dissertation, University of North Carolina, 2008)

Neunsinger, S., 'Die Arbeit der Frauen - die Krise der Männer: Die Erwerbstätigkeit verheirateter Frauen in Deutschland und Schweden 1919-1939' (PhD dissertation, University of Uppsala, 2001)

Quataert, J. H., 'The German Socialist Women's Movement 1890-1918: Issues, Internal Conflicts, and the Main Personages ( $\mathrm{PhD}$ dissertation, University of California, Los Angeles, 1974)

Roos, J., 'Weimar's Crisis through the Lens of Gender: The Case of Prostitution' (PhD dissertation, Carnegie Mellon University, 2001)

Sach, L., “"Gedenke, daß du eine deutsche Frau bist!” Die Ärtzin und Bevölkerungspolitikerin Ilse Szagunn (1887-1971) in der Weimarer Republik und im Nationalsozialismus' (PhD dissertation, University of Berlin, 2006)

Sneeringer, J., 'The Political Mobilisation of Women in Weimar Germany, 1918-1932' (PhD dissertation, University of Pennsylvania, 1995)

Stokes, P. R., 'Contested Conceptions: Experiences and Discourses of Pregnancy and Childbirth in Germany, 1914-1933' (PhD dissertation, Cornell University, 2003)

Todd, L. M., 'Sexual Treason: State Surveillance of Immorality and Infidelity in World War One Germany' (PhD dissertation, University of Toronto, 2005)

Wack, A., 'Frauenarbeit in der Kriegsfürsorge in München' (PhD dissertation, University of Munich, 1918)

Walmsley, J., 'The Political Role of Catholic Women during the Weimar Republic, 1918-1933' (PhD dissertation, University of California Riverside, 2000)

Woodfin, C. G., 'Reluctant Democrats: Women of the Protestant Frauenhilfe and Weimar Politics 1918-1933' (PhD dissertation, University of Nashville, 1997)

\section{Internet sources}

'Gleicher Lohn für gleiche Arbeit: Eckpunkte für geseztliche Regelung', Fraktion Intern, 3 (11 April 2011), 11, www.spdfraktion.de/cnt/rs/ rs_datei/0,,14434,00.pdf (accessed 21 April 2012)

Göttingen chronicle for 15 March 1915, www.stadtarchiv.goettingen.de/ chronik/1915_03htm (accessed 19 July 2007)

Hertling, A., 'Representing Gender: Automobility in Discourse of 
Femininity in the Weimar Republic' (2004), 4-6, www.carstudies.de/ gender/repr_gender/representinggender.pdf (accessed 26 March 2012)

Hessler, M., "Do companies know what women want?" The Introduction of Electrical Domestic Appliances during the Weimar Republic', Technology/Technologies, 13 (1998-99), http://hdl.handle.net/2027/ spo.ark5583.0013.002 (accessed 19 November 2011)

Schoppmann, C., 'Anna Elisabet Weirach (1887-1970)', www.lesbengeschichte.de/bio_weirauch_d.html (accessed 25 July 2012)

Schröder, W. H., W. Weege and M. Zech, Kollektive Biographie der Landtagsabgeordneten der Weimarer Republik 1918-1933 (Cologne: Quantum, 2004), http://biosop.zhsf.uni-koeln.de/ParlamentarierPortal/ bioweil.htm (accessed 5 August 2011)

'Vor 80 Jahren um die Welt', Welt Online (3 March 2007), www.welt.de/ welt_print/article743782/Vor_80_Jahren_um_die_Welt.html (accessed 18 February 2012) 